\title{
A bedside clinical and ultrasound-based approach to hemodynamic instability - Part II: bedside ultrasound in hemodynamic shock: Continuing Professional Development
}

\author{
Annette Vegas, MD • André Denault, MD, PhD • \\ Colin Royse, MD
}

Received: 7 March 2014 / Accepted: 19 August 2014/Published online: 2 October 2014

(C) Canadian Anesthesiologists' Society 2014

\begin{abstract}
Shock is defined as a situation where oxygen transport and delivery is inadequate to meet oxygen demand. The patient in shock is evaluated through medical history, physical examination, and careful observation of the hemodynamic and respiratory monitors. The patient is
\end{abstract}

This Continuing Professional Development module is the second in a two-part series on the management of patients with hemodynamic instability. In this module, the emphasis is placed on the use of ultrasound to manage patients in shock. The first module, published in September 2014 (Can J Anesth 2014; DOI:10.1007/s12630-0140203-0), focused mainly on the clinical approach.

Ce module de Développement professionnel continu est le second d'une série en deux parties portant sur la prise en charge des patients instables hémodynamiquement. Dans ce module, l'emphase est mise sur l'utilisation de l'échographie pour prendre en charge les patients en état de choc. Le premier module, publié en septembre (Can J Anesth 2014; DOI:10.1007/s12630-014-0203-0), traitait principalement de l'approche clinique.

Electronic supplementary material The online version of this article (doi:10.1007/s12630-014-0231-9) contains supplementary material, which is available to authorized users.

A. Vegas, MD

Department of Anesthesiology, Toronto General Hospital,

University of Toronto, Toronto, ON, Canada

A. Denault, $\mathrm{MD}, \mathrm{PhD}(\bowtie)$

Department of Anesthesiology, Critical Care Division, Montreal Heart Institute, 5000 Belanger Street, Montreal, QC H1T 1C8, Canada

e-mail: denault@ videotron.ca; andre.denault@umontreal.ca

A. Denault, $\mathrm{MD}, \mathrm{PhD}$

Department of Medicine, Critical Care Division, Centre

Hospitalier de l'Université de Montréal, Montreal, QC, Canada

C. Royse, MD

Ultrasound Education Unit, Department of Surgery,

The University of Melbourne, Parkville, VIC, Australia initially managed with basic resuscitation measures, however bedside ultrasound should be performed if hemodynamic instability persists. We propose to use ultrasound of the inferior vena cava (IVC), and the concept of venous return, as the initial step in order to identify the mechanism of shock. Doppler examination of the hepatic venous flow can also be added. Further ultrasound examination of the patient's heart, thorax, and abdomen can then be performed in order to determine the etiology of shock. In patients with reduced mean systemic venous pressure, an examination of the patient's thoracic and abdominal cavities to detect free fluid, pneumonia, or empyema can be considered. In patients with increased right atrial pressure, transthoracic echocardiography will allow identification of left or right ventricular dysfunction. Finally, in the presence of increased resistance to venous return, thoracic examination for pneumothorax or cardiac tamponade and abdominal examination for signs of abdominal compartment syndrome or IVC occlusion can be considered. Subsequent treatment can then be tailored to the etiology of shock. Elements of bedside ultrasound examination are currently taught in many anesthesia training programs.

Purpose To develop an approach to the patient in shock that incorporates bedside ultrasound examination.

\section{Objectives of this Continuing Professional Development (CPD) module:}

After reading this second module, the reader should be able to:

1. Identify the indications for point-of-care ultrasound.

2. Use bedside ultrasound to identify the key vascular, cardiac, pulmonary, and abdominal echographic findings that will point towards the etiology of shock. 
Table 1 Common bedside ultrasound protocols

\begin{tabular}{|c|c|c|c|}
\hline Protocol & & $\begin{array}{l}\text { Ultrasound } \\
\text { location }\end{array}$ & Assessment \\
\hline FOCUSED & $\underset{\text { Eltrasound }^{1}}{\text { Focused }^{\text {Cardiac }}}$ & TTE & Cardiac \\
\hline FATE & $\begin{array}{c}\text { Focused Assessed } \\
\text { Transthoracic } \\
\underline{\underline{E}} \text { cho }^{2}\end{array}$ & TTE + pleural & $\begin{array}{l}\text { Cardiac and } \\
\text { lung }\end{array}$ \\
\hline FAST & $\begin{array}{l}\text { Focused } \\
\text { Assessment with } \\
\text { Sonography in } \\
\overline{\text { Trauma }}^{3}\end{array}$ & $\begin{array}{l}\text { TTE, pleural, } \\
\text { abdominal }\end{array}$ & $\begin{array}{l}\text { Cardiac, lung } \\
\text { and } \\
\text { abdomen }\end{array}$ \\
\hline RUSH & $\begin{array}{l}\text { Rapid } \underline{\text { Ultrasound }} \\
\text { for } \underline{\text { Shock and }} \\
\text { Hypotension }\end{array}$ & $\begin{array}{l}\text { TTE, pleural, } \\
\text { abdomen }\end{array}$ & $\begin{array}{l}\text { Cardiac, lung } \\
\text { and } \\
\text { abdomen }\end{array}$ \\
\hline HEARTscan & $\begin{array}{l}\text { Hemodynamic } \\
\text { Echocardiography } \\
\overline{\text { Asssessment in }} \\
\bar{R}_{\text {Real Time }}^{5}\end{array}$ & TTE views & $\begin{array}{l}\text { Cardiac, } \\
\text { hemodynamics }\end{array}$ \\
\hline
\end{tabular}

TTE $=$ transthoracic echocardiography

3. Develop a systematic approach for combining hemodynamic, respiratory, and echocardiographic variables in the assessment of the patient in shock.

4. Identify the limitations of bedside ultrasound.

5. Recognize the training modalities and certification proposed in bedside ultrasound.

\section{Part II}

\section{Introduction}

There have been several proposed approaches for the use of bedside ultrasound in patients with shock. These include the FOCUSED, ${ }^{1}$ FATE, ${ }^{2}$ FAST, ${ }^{3}$ RUSH, ${ }^{4}$ and HEART scan $^{5}$ protocols (Table 1). Common to all of these protocols is the use of "point-of-care ultrasonography" 6 which emphasizes the following three points: (1) the exam is performed at the bedside by the clinician managing the patient; (2) the dynamic images are correlated with the clinical picture; and (3) the exam can be repeated as often as needed to monitor progress.

The clinical approach that we suggest integrates various aspects of bedside ultrasound, including examination of the thorax, heart, abdomen, and vasculature. It classifies the three fundamental mechanisms of shock according to the concept of venous return into: (1) reduction in mean systemic venous pressure, (2) increase in right atrial pressure, and (3) increase in resistance to venous return (Table 2). This approach was the topic of a $\mathrm{PhD}$ thesis $^{7}$ and has been practically applied in the intensive care unit (ICU) of both the Centre Hospitalier de l'Université de Montréal and the Montreal Heart Institute (MHI) with bedside
Table 2 Shock classification using the venous return concept

\begin{tabular}{|c|c|c|}
\hline $\begin{array}{l}\text { Reduced Mean Systemic } \\
\text { Venous Pressure (Pms) }\end{array}$ & $\begin{array}{l}\text { Increased Right } \\
\text { Atrial Pressure } \\
\text { (Pra) }\end{array}$ & $\begin{array}{l}\text { Increased Resistance } \\
\text { to Venous Return } \\
\text { (Rvr) }\end{array}$ \\
\hline $\begin{array}{l}\text { Hemorrhagic shock } \\
\text { External } \\
\text { Internal: thorax, } \\
\text { abdominal } \\
\text { Distributive shock } \\
\text { Septic } \\
\text { Non-septic: } \\
\text { anaphylactic } \\
\text { endocrine (adrenal } \\
\text { and thyroid } \\
\text { function) } \\
\text { liver failure } \\
\text { neurogenic and } \\
\text { neuroaxial } \\
\text { blockade } \\
\text { pharmacological } \\
\text { and toxic } \\
\text { post CPR and CPB } \\
\text { inflammatory } \\
\text { reactions: burns, } \\
\text { pancreatitis, } \\
\text { multiple trauma, } \\
\text { SIRS }\end{array}$ & $\begin{array}{l}\text { Systolic and } \\
\text { diastolic } \\
\text { dysfunction } \\
\text { (ischemic or } \\
\text { not) } \\
\text { Acute valvular } \\
\text { insufficiency } \\
\text { Outflow tract } \\
\text { obstruction } \\
\text { Pulmonary } \\
\text { embolism } \\
\text { Hypoxemia and } \\
\text { hypercapnia }\end{array}$ & $\begin{array}{l}\text { Extrinsic: } \\
\text { Supra- } \\
\text { diaphragmatic: } \\
\text { tamponade } \\
\text { pneumothorax } \\
\text { mediastinal } \\
\text { tamponade } \\
\text { severe } \\
\text { hyperinflation } \\
\text { (auto-PEEP) } \\
\text { Infra-diaphragmatic: } \\
\text { abdominal } \\
\text { compartment } \\
\text { syndrome } \\
\text { (intraluminal, } \\
\text { extraluminal, and } \\
\text { parietal) } \\
\text { Intrinsic: IVC } \\
\text { obstruction } \\
\text { from sutures, } \\
\text { tumours, devices }\end{array}$ \\
\hline
\end{tabular}

IVC $=$ inferior vena cava; $\mathrm{PEEP}=$ positive-end-expiratory pressure; $\mathrm{CPR}=$ cardiopulmonary $\quad$ resuscitation $; \quad \mathrm{CPB}=$ cardiopulmonary bypass; SIRS $=$ systemic inflammatory response

surface ultrasound since 1996 and at the MHI operating room using transesophageal echocardiography (TEE) in over 22,000 cases since 1999.

Though both transthoracic echocardiography (TTE) and TEE can be used at the bedside, our focus is on the use of TTE, as this technique is more widely available to all anesthesiologists and critical care physicians. Finally, we do not detail the lung examination as our approach to hypoxemia was the topic of a recent review article. ${ }^{8}$

Ultrasound imaging

\section{Ultrasound imaging of the IVC}

The first step when dealing with the hemodynamically unstable patient who is unresponsive to standard care is to identify the underlying mechanism of shock. This can be determined by rapidly examining the size and respiratory variation of the inferior vena cava (IVC) in the spontaneously breathing patient. Ultrasound interrogation of the IVC is classically performed using a subxiphoid view (Fig. 1-1). In some patients, the presence of chest tubes or dressings may prevent access to this view. 

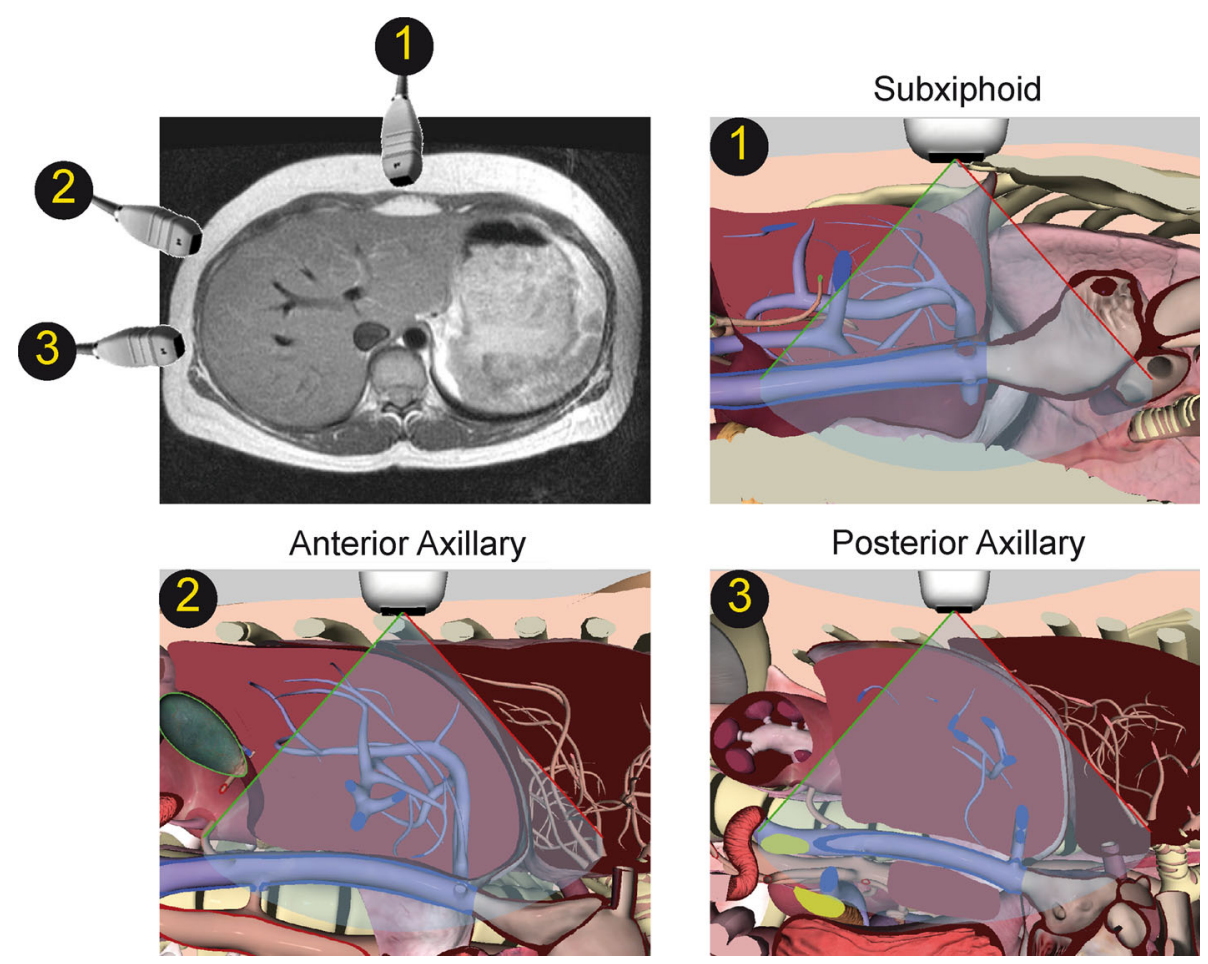

Fig. 1 Ultrasound of the IVC. Axial computed tomographic scan of the liver showing different positions of the ultrasound probe that can be used to obtain a longitudinal view of the inferior vena cava (IVC). The (1) subxiphoid (See video 01_1), (2) anterior axillary line (See video 01_2), and (3) posterior axillary line (See video 01_3) probe positions are shown using the VIMEDIX $^{\circledR}$ simulator (CAE Healthcare, Saint-Laurent, QC, Canada). The subxiphoid view is obtained in the supine patient by positioning the probe in the subcostal region with the probe marker placed towards the head at 12 o'clock. The ultrasound plane is directed towards the liver to show a longitudinal view of the IVC. A short-axis view of the IVC may be obtained by rotating the probe by $90^{\circ}$. The IVC must be distinguished from the pulsatile aorta by identifying (A) the IVC draining into the right atrium, (B) liver surrounding the IVC, (C) lack of pulsatility of the IVC (unless severe tricuspid regurgitation is present), and (D) hepatic veins draining into the IVC. In this Figure, the head is positioned at the right of the image

Table 3 Limitations to using the IVC to estimate mean systemic venous pressure

\section{Mechanical obstruction: \\ prominent Eustachian valve, web, tissue, tumour, thrombus, aortic aneurysm, foreign body such as filters present in the IVC, narrowing of the IVC-right atrial junction \\ Others: \\ athletic training, large body surface area, mechanical ventilation}

$\mathrm{IVC}=$ inferior vena cava. (Adapted from Beigel et al. $)^{34}$

Fortunately, since the distal portion of the IVC is intrahepatic and the liver is large, imaging through the liver from any lower right intercostal position provides an
Échographie de la veine cave inférieure. Tomodensitométrie axiale du foie montrant les différentes positions de la sonde d'échographie qui peuvent être utilisées pour obtenir une vue longitudinale de la veine cave inférieure (VCI). Les positions de la sonde sur les lignes (1) sous-xiphoïdienne (voir vidéo 01_1), (2) axillaire antérieure (voir vidéo 01_2), et (3) axillaire postérieure (voir vidéo 01_3) sont montrées à l'aide du simulateur VIMEDIX ${ }^{\circledR}$ (CAE Healthcare, Saint-Laurent, QC, Canada). La vue sous-xiphoïdienne est obtenue chez le patient couché sur le dos en positionnant la sonde dans la région sous-costale avec l'indicateur de position de la sonde placé en direction de la tête à midi. Le plan d'imagerie échographique est dirigé vers le foie afin de montrer une vue longitudinale de la VCI. Une vue en axe court de la VCI peut être obtenue en tournant la sonde de $90^{\circ}$. La VCI peut être distinguée de l'aorte pulsatile en identifiant (A) la VCI se vidant dans l'oreillette droite, (B) le foie entourant la VCI, (C) l'absence de pulsatilité de la VCI (sauf s'il y a régurgitation tricuspide grave), et (D) les veines hépatiques se vidant dans la VCI. Dans cette figure, la tête est positionnée à la droite de l'image

acoustic window to the IVC (Figs. 1-2 \& 1-3). The ability to image the IVC in the vast majority of patients justifies our choice of the IVC rather than the heart for this initial portion of the TTE ultrasound examination in a patient in shock. There are, however, limitations to using the IVC to estimate mean systemic venous pressure (see Table 3).

In a normal individual receiving positive pressure ventilation, the IVC increases in size during inspiration (from increased intrathoracic pressure) and decreases in size during expiration. This constitutes a reversal of the respiratory pattern observed in spontaneously breathing patients. Thus, changes in IVC diameter can still be used to assess fluid responsiveness in patients whose lungs are mechanically ventilated. ${ }^{9}$ 


\section{A}

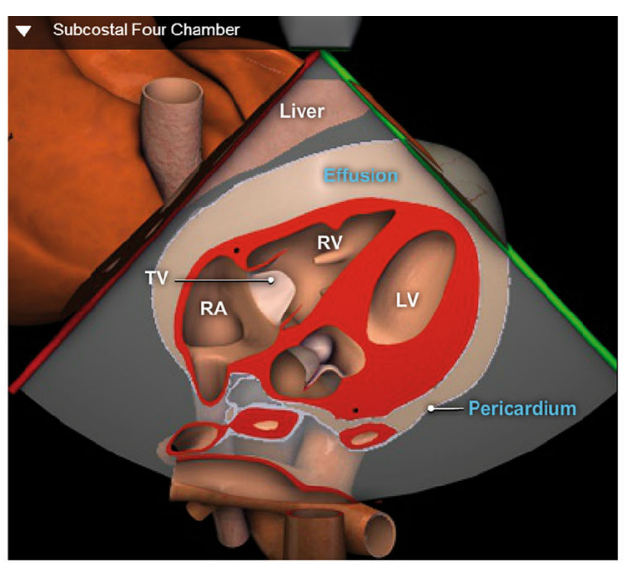

B

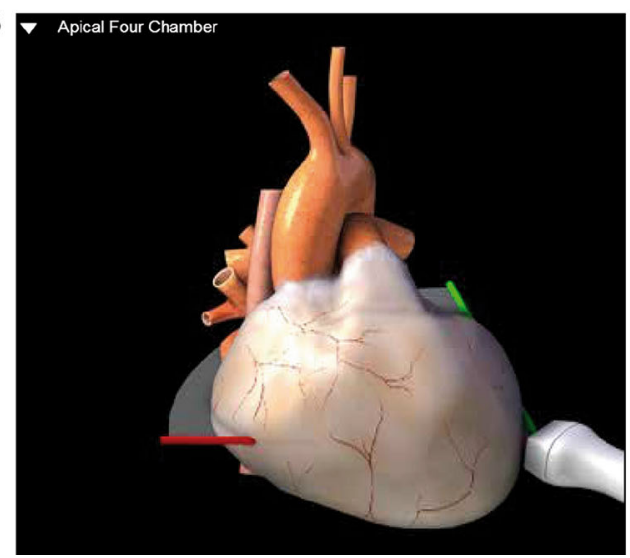

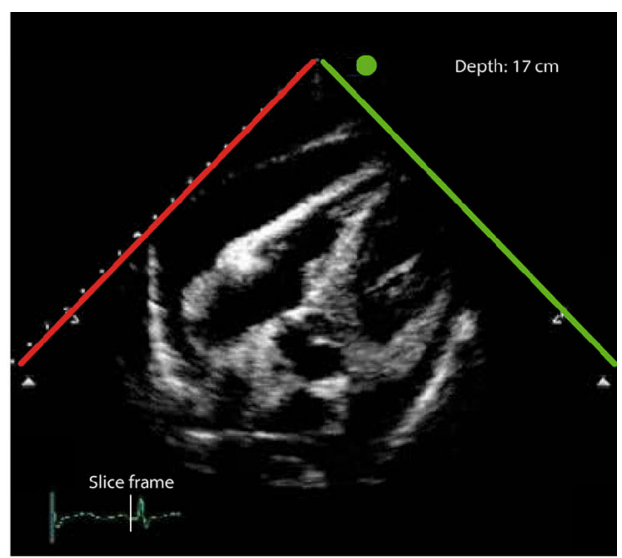

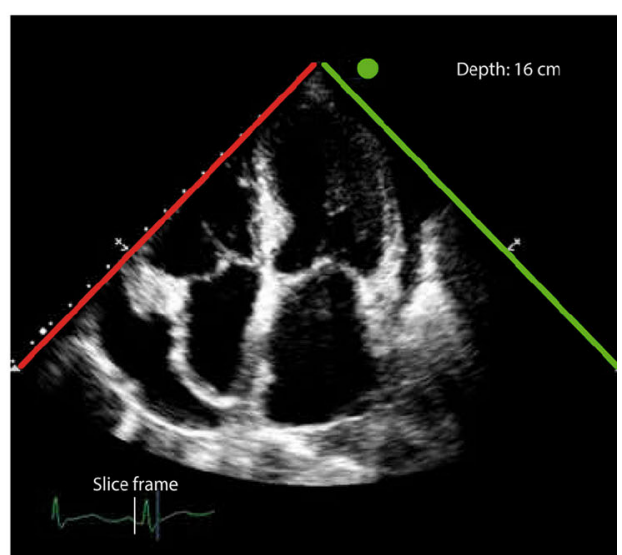

Fig. 2 Transthoracic echocardiography (TTE) views. (A) A TTE subxiphoid four-chamber view of the heart and corresponding anatomic diagram showing a large circumferential pericardial effusion. (B) The same circumferential effusion is seen in a TTE apical four-chamber view. (Images used with permission from A. Vegas: http://pie.med.utoronto.ca/TTE)

In order to identify the precise underlying etiology causing shock, it is also necessary to examine the heart. A simple way to view the heart from the subxiphoid IVC view is to rotate the ultrasound probe clockwise to obtain a subcostal view showing all four cardiac chambers, which is analogous to a TTE apical four-chamber view (Fig. 2). In addition to the subxiphoid approach, there are several other useful echocardiographic views for examining the heart, as reviewed by Royse et al. ${ }^{10}$

\section{Imaging in reduced mean systemic pressure}

In spontaneously breathing patients, reduced mean systemic venous pressure is typically associated with a small IVC that varies in dimension with respiration. This can be demonstrated easily using $2 \mathrm{D}$ and $\mathrm{M}$-mode imaging (Fig. 3). Another useful echocardiographic feature to evaluate mean systemic venous pressure is to interrogate the hepatic vein flow (HVF) using pulsed wave Doppler in the hepatic vein. The normal HVF generates a triphasic
Images d'échocardiographie transthoracique (ÉTT). (A) Vue sous-xiphoïdienne des quatre chambres du cœur par ÉTT et diagramme anatomique montrant un important épanchement péricardique circonférentiel. (B) Le même épanchement circonférentiel observé dans une vue apicale des quatre chambres par ÉTT. (Images utilisées avec la permission de A. Vegas: http://pie.med.utoronto.ca/TTE)

Doppler waveform (Fig. 4). In certain cases of reduced mean systemic venous pressure, the HVF velocity can be increased because the hepatic vein is smaller in size, and consequently, blood flow velocity is higher in this smaller vessel. Detailed analysis of hepatic vein Doppler waveform is beyond the scope of this article, but excellent reviews have been written by Scheinfeld and McNaughton. ${ }^{11,12}$

Once reduced mean systemic venous pressure is identified as a mechanism of shock, the next step is to identify the etiology. Two possible causes are blood loss and vasodilatation. Point-of-care measurement of hemoglobin can quickly distinguish between the two, although in acute hemorrhage, hematocrit values may remain normal for a while because the associated reduced plasma volume is paired with reduction in red blood cells. ${ }^{13,14}$ The blood loss can be from external or internal causes, including into the thorax, peritoneal cavity, retroperitoneal cavity, pelvis, long bones, or gastrointestinal tract. Identification of a hemothorax and free fluid in the abdomen (Fig. 5A-C) can be easily 


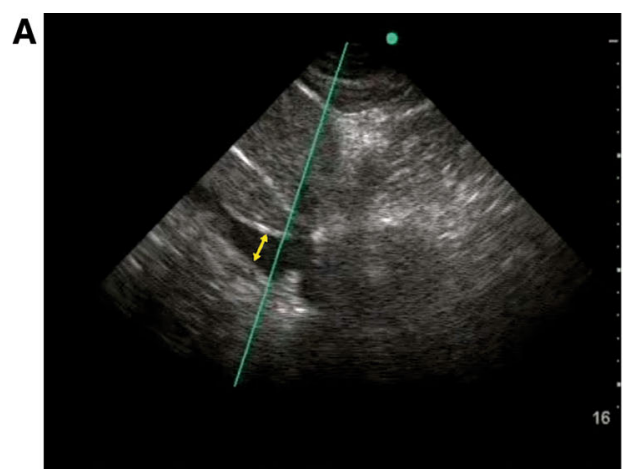

Fig. 3 Inferior vena cava diameter and respiratory variation. (A) Subxiphoid view showing a longitudinal orientation of the inferior vena cava (IVC) (See video 03a) with (B) complete inspiratory collapse using M-mode (See video 03b). In order to adequately assess the IVC, it is important to maintain a stable ultrasound image while adjusting the M-mode cursor. Respiration can cause the probe to move which can lead to false variation in IVC diameter. The walls of the IVC should be parallel to avoid an oblique measurement which can underestimate the cross-sectional diameter. The ultrasound probe should be manipulated until the maximum IVC diameter is shown, as any imaging that is off-centre will underestimate the size of the IVC (cylinder tangent artifact). Thus, there is some value in examining the IVC in short axis and in estimating variability visually (eyeball method) even as the target "moves". The diameter of the IVC should be measured within $3 \mathrm{~cm}$ of entering the right atrium using the $2 \mathrm{D}$ image or M-mode. The maximum diameter (yellow arrow) at end expiration and minimal diameter at end inspiration of the IVC should be recorded. The normal IVC diameter is $1.5-2.5 \mathrm{~cm}$ with less than $50 \%$ inspiratory collapse in a spontaneously breathing patient. In this Figure, the head is positioned at the right of the image

accomplished with bedside ultrasound. Retroperitoneal hemorrhage is more difficult to diagnose with ultrasound, and computed tomography (CT) is a better diagnostic modality (Fig. 5D-F). In some patients, blood clots can be seen in the stomach with TTE or TEE (Fig. 6). Ultrasound is not as reliable as upper and lower endoscopy to diagnose gastrointestinal bleeding, as blood in the stomach can appear similar to enteral solutions in ultrasound images.

If blood loss is not the cause of the reduced mean systemic venous pressure, then a septic condition needs to be ruled out by clinical and laboratory examination. Limited TTE views of the heart may show large vegetations. Lung consolidation and a complex effusion in the chest or abdomen can be diagnosed easily with ultrasound (Fig. 7). The diagnosis of a liver abscess, cholecystitis, and pyelonephritis requires more advanced skills in bedside ultrasound. Bedside ultrasound is of limited utility in some conditions associated with distributive shock, e.g., anaphylactic shock, pharmacological central blockade, and Addisonian crisis.

Echocardiography may help distinguish between hypovolemia and vasodilatation. In hypovolemia, the

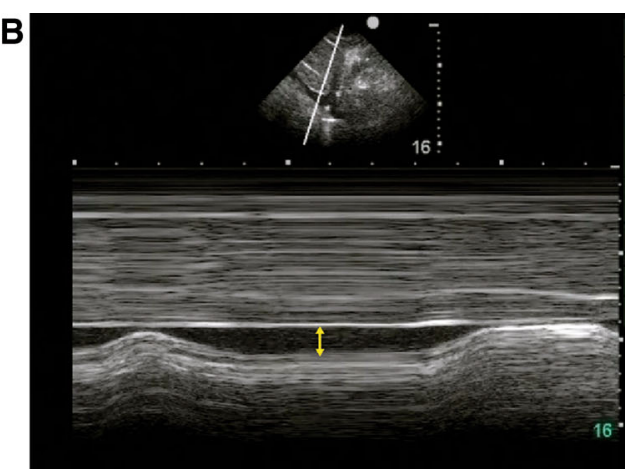

Diamètre de la veine cave inférieure et variation respiratoire. (A) Vue sous-xiphoïdienne montrant une orientation longitudinale de la veine cave inférieure (VCI) (voir vidéo 03a) avec (B) collapsus inspiratoire complet en utilisant le mode $\mathrm{M}$ (voir vidéo 03b). Afin d'évaluer correctement la VCI, il est important de maintenir une image d'échographie stable lors de l'ajustement du curseur en mode M. La respiration peut faire bouger la sonde, ce qui peut causer une fausse variation dans le diamètre de la VCI. Les parois de la VCI doivent être parallèles afin d'éviter une mesure oblique, laquelle pourrait sous-estimer le diamètre transverse. La sonde d'échographie doit être manipulée jusqu'à voir le diamètre maximal de la VCI, étant donné que toute image non centrée sous-estimera la taille de la VCI (artéfact tangentiel). Ainsi, il est utile d'examiner la VCI en court-axe et d'estimer la variabilité de façon visuelle même lorsque la cible «bouge ». Le diamètre de la VCI devrait être mesuré dans les $3 \mathrm{~cm}$ précédant l'entrée dans l'oreillette droite en utilisant une image en 2D ou en mode $M$. Le diamètre maximal (flèche jaune) en fin d'expiration et le diamètre minimal en fin d'inspiration de la VCI doivent être enregistrés. Le diamètre normal de la VCI est de 1,5-2,5 $\mathrm{cm}$ avec moins de $50 \%$ de collapsus inspiratoire chez un patient respirant spontanément. Dans cette figure, la tête est positionnée à la droite de l'image

ventricles typically have a small end-diastolic and end-systolic size (volume) with normal ejection fraction. In a patient with vasodilatation, the end-diastolic size will be normal with a small end-systolic size representing an increased ejection of blood against lower resistance. This distinction may be difficult to make in a patient with rapidly changing hemodynamic states, or when both conditions are present simultaneously, particularly in those whom the baseline end-diastolic volume is unknown.

\section{Imaging in elevated right atrial pressure}

In the presence of cardiogenic shock, an elevated right atrial pressure is associated with a distended IVC with no respiratory variation and reduced systolic:diastolic ratio in the HVF Doppler profile (Fig. 4). If cardiogenic shock is suspected, further echocardiographic evaluation is required to decide if the cause is related to left ventricular (LV) pathology, right ventricular (RV) pathology, valvulopathies, pulmonary hypertension, severe tricuspid regurgitation, intracardiac shunts, or other causes such as pulmonary embolism. The 


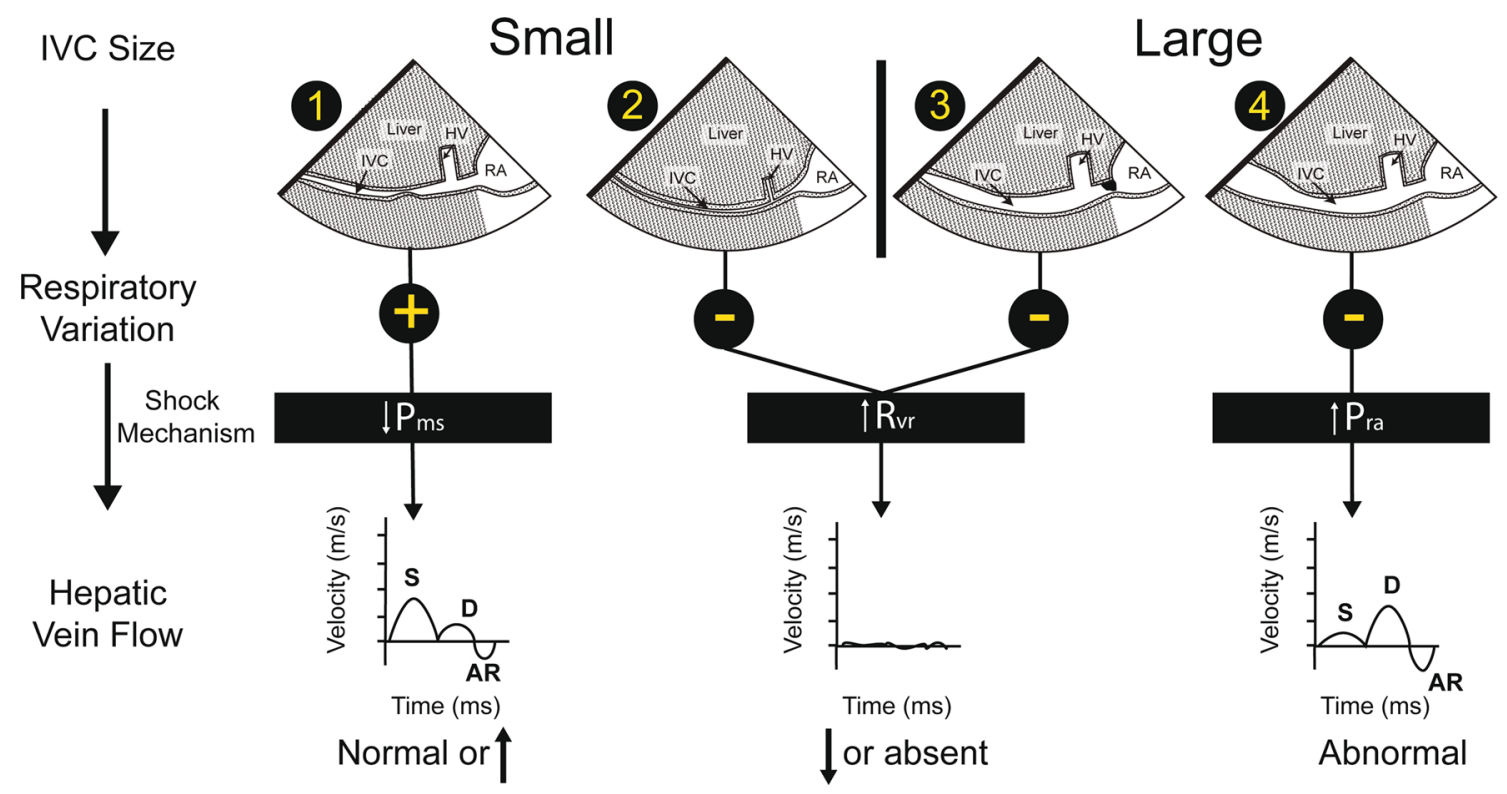

Fig. 4 Shock mechanism. Algorithm to determine shock mechanism using inferior vena cava (IVC) size, respiratory variation during spontaneous ventilation, and hepatic venous flow (HVF). In patients with reduced mean systemic venous pressure (Pms), the IVC is small with respiratory variation (1), and the HVF is typically normal or increased due to the reduced dimension of the hepatic vein. In patients with increased resistance to venous return (Rvr), the IVC can be collapsed from an abdominal compartment syndrome (2) or distended from a mechanical obstruction at the junction of the IVC and right atrium (RA) (3). The HVF signal will be significantly reduced, monophasic, or absent in both situations. In a situation where the right atrial pressure (Pra) is increased, the IVC is dilated without respiratory variation (4), and the HFV will be abnormal with reduced systolic (S) to diastolic (D) velocity ratio. Table 2 lists the conditions associated with the different mechanisms. $\mathrm{AR}=$ atrial reversal velocity of the HVF; $\mathrm{HV}=$ hepatic vein. (Adapted with permission from Denault AY $)^{7}$

subxiphoid four-chamber view can be used to screen for many of these pathologies. The presence of systolic dysfunction would suggest the need for inotropes. Detailed evaluation of biventricular function has been reviewed by many authors. ${ }^{15,16}$ It is important to point out that not all myocardial depression is ischemic in origin. For instance, in septic shock, a catecholamine-induced cardiomyopathy can be found in up to $60 \%$ of patients when an echocardiographic examination is performed within three days of admission. ${ }^{17}$ Right ventricular failure can result from pulmonary embolism or chronic pulmonary hypertension from any cause. A chest CT scan remains the preferred diagnostic modality for pulmonary embolism. Nevertheless, 2D echocardiography can document a thrombus in transit. It is also useful to assess the consequences of pulmonary artery obstruction, such as RV dilatation with reduced systolic excursion, and small-sized left atrium and LV from less blood transiting to the left side.
Mécanisme du choc. Algorithme servant à déterminer le mécanisme du choc en utilisant la taille de la veine cave inférieure (IVC), la variation respiratoire pendant la ventilation spontanée, et le flux veineux hépatique $(\mathrm{FVH})$. Chez les patients présentant une pression veineuse systémique moyenne (Pms) réduite, l'IVC est petite et varie avec la respiration (1). Le FVH est en général normal ou accru en raison de la dimension réduite de la veine hépatique. Chez les patients présentant une résistance accrue au retour veineux (Rvr), l'IVC peut être collabée en raison d'un syndrome du compartiment abdominal (2) ou distendue en raison d'une obstruction mécanique à la jonction de l'IVC et de l'oreillette droite (RA) (3). Le signal du FVH sera significativement réduit, monophasique ou absent, dans les deux cas. Lorsque la pression auriculaire droite (Pra) est accrue, l'IVC est dilatée sans variation respiratoire (4), et le FVH sera anormal avec un ratio de vélocité systolique (S) à diastolique (D) réduit. Le Tableau 2 énumère les conditions associées aux différents mécanismes. $\mathrm{AR}=$ vélocité de la contraction auriculaire qui est typiquement renversée au niveau du FVH; $\mathrm{HV}=$ veine hépatique. (Adapté avec la permission de AY Denault) ${ }^{7}$

Both LV and RV outflow tract obstruction can increase right atrial pressure. These conditions occur in patients with a predisposed anatomy and reduced preload, or in those receiving inotropic agents that can cause tachycardia and reduce ventricular filling time. ${ }^{18,19}$ Administration of volume and beta-blockers (which reduce inotropy) will often correct this condition. The diagnosis of outflow tract obstruction has also been reviewed previously. ${ }^{19,20}$ Mechanical compression of the RV outflow tract can occur with an anterior pneumothorax, in which case, obstruction will initially be seen only in diastole (Fig. 8). It has also been described in the prone position or with an anterior mediastinal hematoma after cardiac surgery. ${ }^{21}$

A common cause of increased right atrial pressure is $\mathrm{LV}$ diastolic dysfunction, which may present as cardiogenic shock. ${ }^{22}$ Dilated atria are typically present. There are two patterns of diastolic failure which can be associated with either (1) a small LV and normal ejection fraction, or (2) a dilated LV and reduced ejection fraction. There is no 
A

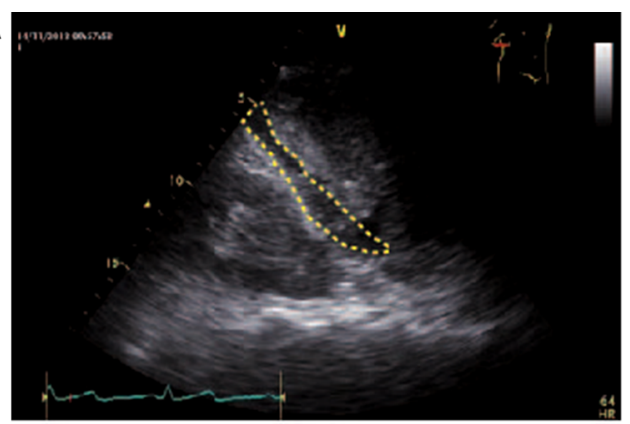

B

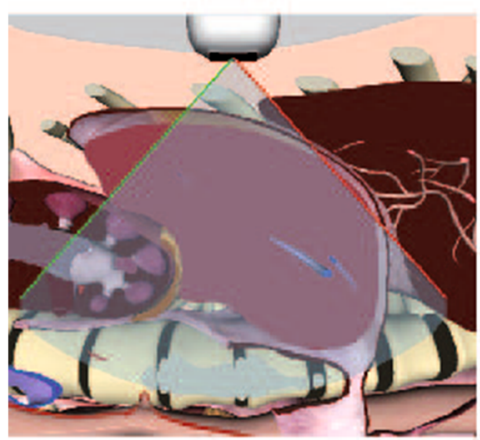

C

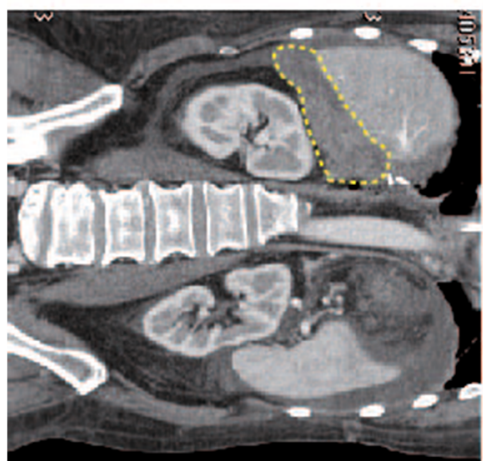

Fig. 5 Abdominal bleeding. (A) Hematoma (dotted area) in the hepatorenal space (Morison's space) shown using ultrasound in a posterior axillary longitudinal view (See video 05A). (B) VIMEDIX ${ }^{\circledR}$ simulator (CAE Healthcare, Saint-Laurent QC, Canada) showing the position of the ultrasound beam in the right coronal anatomical plane without hematoma (See video 05B) and (C) corresponding rotated computed tomography (CT) scan with hematoma (dotted area). (D) A retroperitoneal hematoma (dotted area) is seen with ultrasound using a left coronal posterior axillary view (See video 05D). The VIMEDIX simulator shows the corresponding (E) anatomical position of the ultrasound beam without hematoma (See video 05E). (F) The corresponding CT scan is shown with the retroperitoneal hematoma (dotted area). In this Figure, the head is positioned at the right of the image

specific treatment for diastolic heart failure in the perioperative period except to treat myocardial ischemia if present. $^{23}$

Finally, both hypoxemia and hypercapnia can lead to pulmonary hypertension and RV failure. Lung ultrasound can help to identify the presence of a pneumothorax, pleural effusion, lung consolidation, atelectasis, and

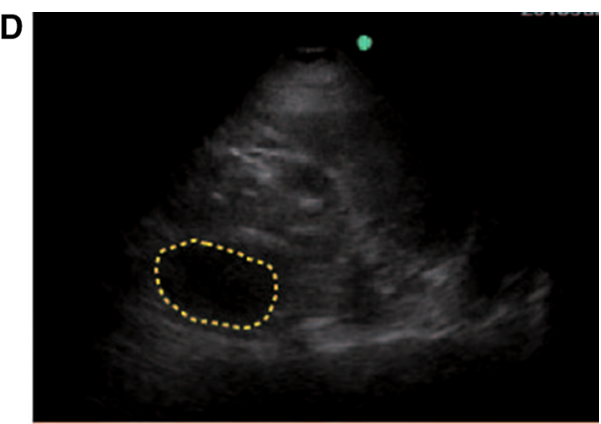

E
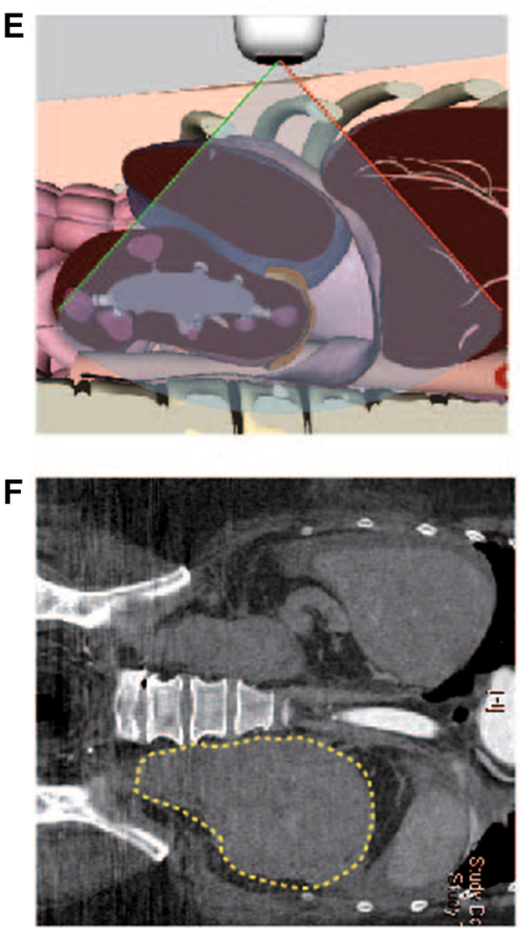

Saignement abdominal. (A) Hématome (zone en pointillé) dans l'espace hépatorénal (espace de Morison) observé par échographie réalisée dans une vue longitudinale axillaire postérieure (voir vidéo 05A). (B) Simulateur VIMEDIX ${ }^{\circledR}$ (CAE Healthcare, Saint-Laurent QC, Canada) montrant la position du faisceau d'échographie dans le plan anatomique frontal droit sans hématome (voir vidéo 05B) et (C) image tomodensitométrique correspondante (CT scan) avec hématome (zone en pointillé). (D) Un hématome rétropéritonéal (zone en pointillé) est vu par échographie via une vue axillaire postérieure coronale gauche (voir vidéo 05D). Le simulateur VIMEDIX montre la position anatomique correspondante (E) du faisceau d'échographie sans hématome (voir vidéo 05E). (F) Le CT scan correspondant démontre l'hématome (zone en pointillé). Dans cette figure, la tête est positionnée à la droite de l'image

congestion. $^{8}$ If the presence of heart failure by echocardiography is coupled with a pulmonary ultrasound examination showing an interstitial edema pattern in all lung zones, this would indicate acute pulmonary venous congestion and suggest a more severe degree of heart failure. In cases of unexplained hypoxemia in the absence of increased ventilatory resistance or reduced pulmonary 

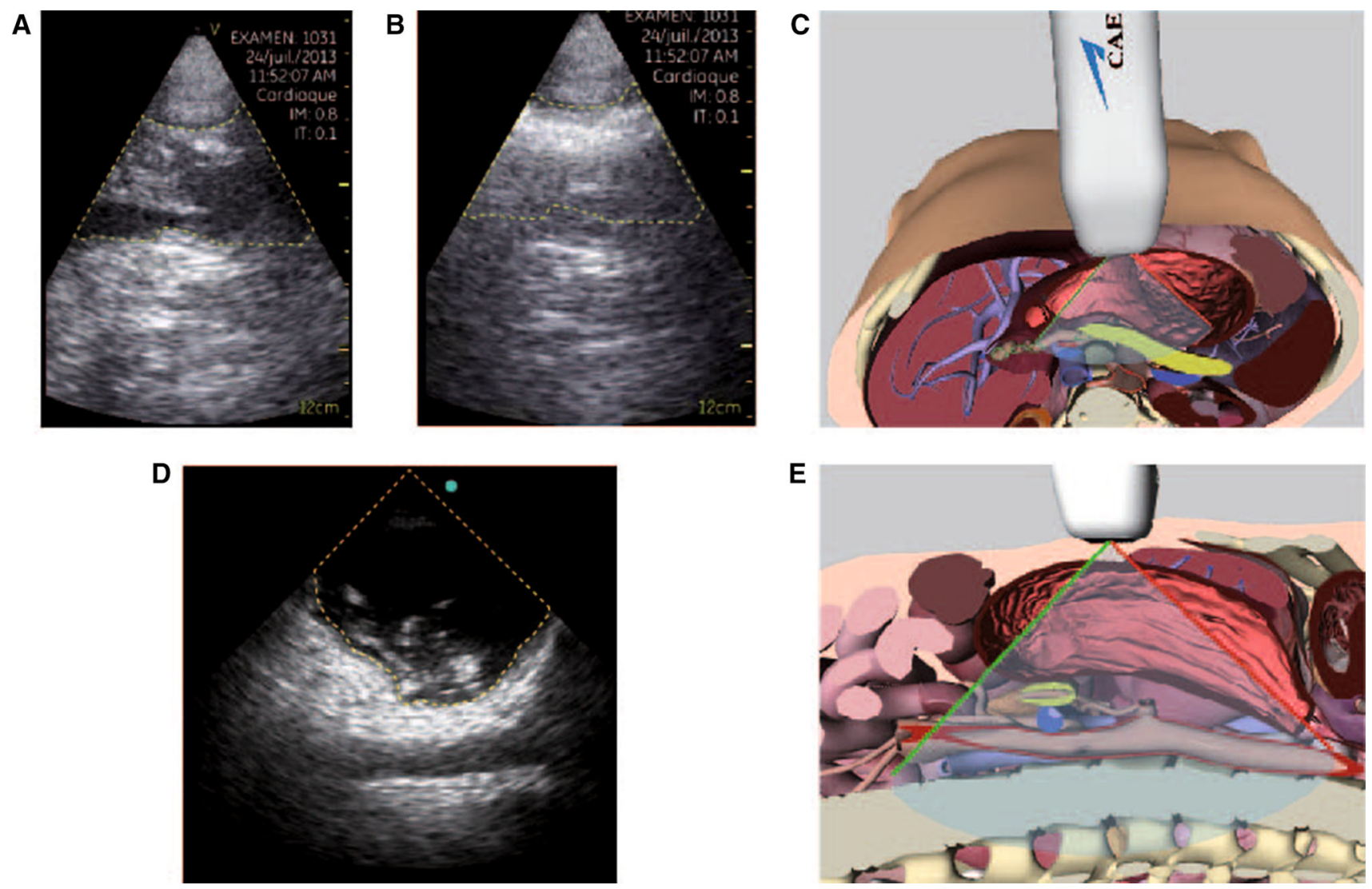

Fig. 6 Gastric fluid. An ultrasound transverse view showing stomach contents (dotted area) in the subxiphoid region before (A) and (B) after injecting air through the nasogastric tube (See video 06ab). This procedure helps to differentiate fluid in the stomach from free abdominal fluid. (C) Corresponding anatomical position of the ultrasound probe with the VIMEDIX ${ }^{\circledR}$ simulator (CAE Healthcare, Saint-Laurent QC, Canada). (D) Sagittal view of a full stomach with blood clots (dotted area) (See video 06d) (E) and corresponding anatomical position of the ultrasound beam using the VIMEDIX simulator

compliance, clinicians should look for an intracardiac shunt (even a small patent foramen ovale) with right to left flow.

\section{Imaging in increased resistance to venous return}

Hemodynamic instability from increased resistance to venous return is less common and can be insidious; failure to diagnose this condition can easily result in death. The IVC may be small or dilated depending on the etiology (Fig. 9). The HVF Doppler spectral display typically has a monophasic or absent waveform (Fig. 4) because the lower pressure gradient between the mean systemic venous pressure and right atrial pressure reduces the hepatic vein flow. The IVC will typically be small and almost completely compressed in patients with abdominal compartment syndrome. ${ }^{24}$ The IVC will be dilated in patients with cardiac tamponade, pneumothorax,
Contenu gastrique. Une vue transverse par échographie montrant le contenu de l'estomac (zone en pointillé) dans la région sous-xiphoïdienne avant (A) et (B) après l'injection d'air via la sonde nasogastrique (voir vidéo 06ab). Cette intervention aide à distinguer le liquide dans l'estomac du liquide abdominal libre. (C) Position anatomique correspondante de la sonde d'échographie avec le simulateur VIMEDIX ${ }^{\circledR}$ (CAE Healthcare, Saint-Laurent QC, Canada). (D) Vue sagittale d'un estomac plein avec des caillots sanguins (zone en pointillé) (voir vidéo 06d) (E) et position anatomique correspondante du faisceau échographique à l'aide du simulateur VIMEDIX

mediastinal tamponade, and intrinsic positive endexpiratory pressure (PEEP), as flow to the heart is reduced. In patients with iatrogenic IVC occlusion or intrinsic obstruction, the intrahepatic IVC will also be distended. This condition can occur with liver transplantation, IVC cannulation during cardiac surgery, ${ }^{25}$ or IVC anastomosis during cardiac transplantation. The key echocardiographic features in such cases are narrowing of the IVC lumen and flow acceleration with colour Doppler (Fig. 9). Confirmation of the hemodynamic gradient by IVC catheterization is used only when considering IVC stenting.

\section{Management of shock}

Identifying the mechanism and etiology of shock is important in order to select the best form of therapy. For 


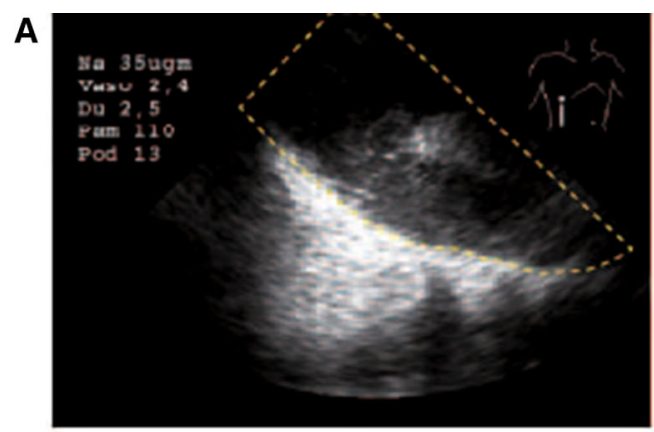

B
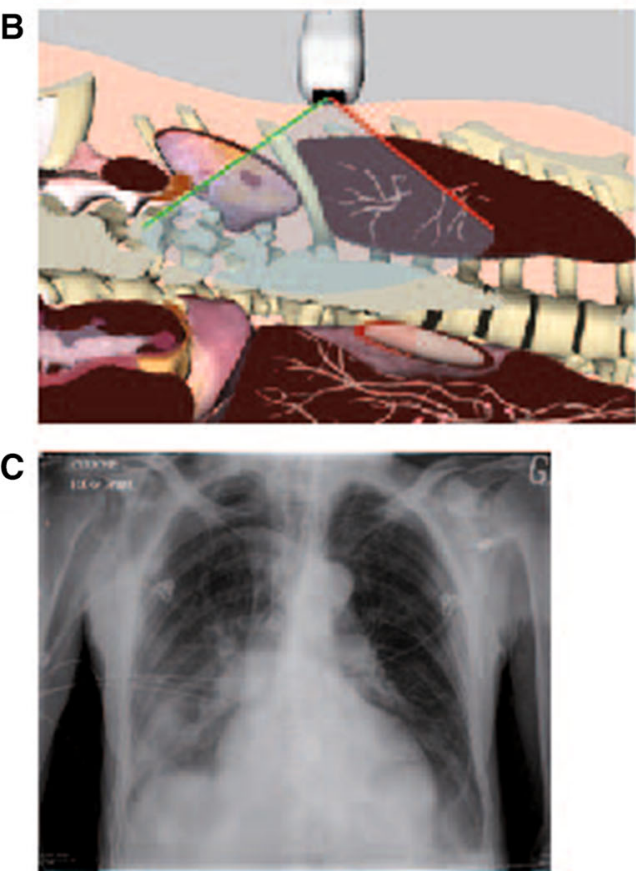

Fig. 7 Fluid collections. (A) Right coronal posterior axillary view using ultrasound showing a complex pleural effusion in a febrile patient (dotted area) (See video 07A). (B) The corresponding anatomical position of the ultrasound beam using the VIMEDIX ${ }^{\circledR}$ simulator (CAE Healthcare, Saint-Laurent QC, Canada) and (C) the abnormal chest radiograph is shown. The patient required chest tube drainage and received broad spectrum antibiotics. (D) Anterior axillary longitudinal view of the inferior vena cava (IVC) using ultrasound in a febrile patient with a subdiaphragmatic complex effusion (dotted area) seen above the liver (See video 07D). (E) Corresponding anatomical position of the ultrasound beam shown with the VIMEDIX simulator. In this Figure, the head is positioned to the right of the image

example, reduced mean systemic venous pressure can be treated with the administration of volume, blood products, antibiotics, and vasopressors. An IVC examination can also be used to predict fluid responsiveness and to monitor the effect of fluid administration in a spontaneously breathing patient or in a patient receiving mechanical ventilation. ${ }^{9}$ Serial measurements of the IVC size and respiratory variation can be more sensitive than blood pressure measurements to assess the effect of fluid resuscitation in
D

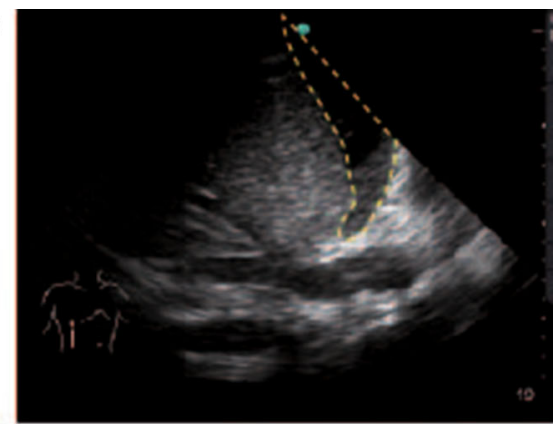

E

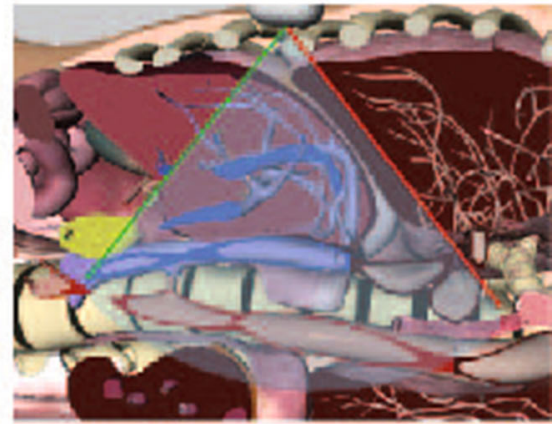

Collections liquidiennes. (A) Vue coronale axillaire postérieure droite par échographie montrant un épanchement pleural complexe chez un patient fébrile (zone en pointillé) (voir vidéo 07A). (B) La position anatomique correspondante de la sonde d'échographie avec le simulateur VIMEDIX $^{\circledR}$ (CAE Healthcare, Saint-Laurent QC, Canada) et (C) la radiographie anormale des poumons sont montrées. Un drain thoracique a été installé et des antibiotiques à large spectre ont été administrés. (D) Vue longitudinale axillaire antérieure de la veine cave inférieure (VCI) par échographie chez un patient fébrile avec un épanchement sous-diaphragmatique complexe (zone en pointillé) observé au-dessus du foie (voir vidéo 07D). (E) Position anatomique correspondante du faisceau d'échographie montré avec le simulateur VIMEDIX. Dans cette figure, la tête est positionnée à la droite de l'image

patients. Vasopressors may be beneficial to prevent excessive fluid administration in the presence of vasodilatation. In some situations, adrenal supplementation, antihistamines, adrenaline, or even methylene blue might be considered in refractory vasoplegic states.

The management of elevated right atrial pressure depends on the underlying etiology as determined by echocardiography. For instance, inotropic agents should be 

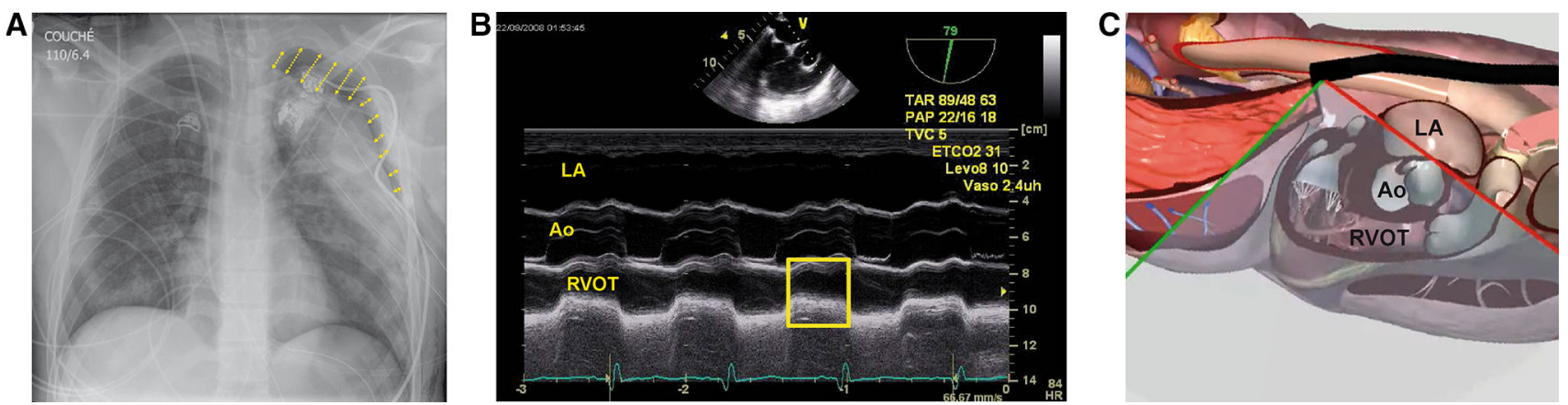

Fig. 8 Transesophageal echocardiographic view of a right ventricular outflow tract with (RVOT) diastolic obstruction. (A) Chest radiograph showing a left pneumothorax in a hemodynamically unstable 19-yr-old man with a chest contusion is admitted for organ donation. The arrows indicate the extent of the pneumothorax. (B) Using transesophageal echocardiography, a mid-esophageal view of the RVOT or a right ventricular "wrap around view" shows diastolic obstruction of the RVOT with M-mode. This obstruction was from the anterior portion of the left pneumothorax compressing the RVOT. (C) The anatomical position of the ultrasound beam shows how the lingula portion of the left lung lies anterior to the RVOT (See video 08). (With permission from Denault $A Y) .^{7}$ Ao $=$ aorta; LA $=$ left atrium

considered if systolic dysfunction is present but are contraindicated in managing outflow tract obstruction. Agents given through inhalation such as prostacyclin, milrinone, or nitric oxide will help manage RV failure. The maintenance of systemic arterial pressure and RV systolic function is also important to manage RV failure and may require a combination of drugs, such as an inodilator with a vasopressor. Thrombolysis or urgent cardiac surgery may be indicated in the presence of acute pulmonary embolism. Correction of hypoxemia and hypercapnia will be successful only if a treatable cause is identified. Ultrasound of the respiratory system can be very useful in such situation. Adequate ventilation to normalize an elevated $\mathrm{PaCO}_{2}$ may reduce the degree of pulmonary hypertension.

Finally, the treatment of increased resistance to venous return is typically non-pharmacological and includes chest tube drainage, pericardiocentesis, positioning (pregnancy), laparotomy, and adjusting the ventilator if auto-PEEP is present. A large pleural effusion, excessive PEEP (external or auto), a gravid uterus, morbid obesity, ascites, and pericardial effusion are all causes of extrinsic IVC and cardiac compression that may induce diastolic failure. Tamponade is a severe form of "acute diastolic failure" as the pericardial fluid physically compresses the heart chambers.
Vue échocardiographique transœsophagienne d'une obstruction diastolique de la chambre de chasse du ventricule droit (RVOT). (A) Radiographie thoracique montrant un pneumothorax gauche chez un homme de 19 ans instable hémodynamiquement avec contusion thoracique admis pour don d'organes. Les flèches indiquent l'étendue $\mathrm{du}$ pneumothorax. (B) À l'aide d'une échocardiographie transœsophagienne, une vue mid-œsophagienne de la chambre de chasse du ventricule droit ou une vue wrap around du ventricule droit montre une obstruction diastolique de la chambre de chasse du ventricule droit en mode $M$. Cette obstruction était due à la partie antérieure du pneumothorax gauche comprimant la chambre de chasse du ventricule droit. (C) La position anatomique du faisceau échographique montre comment la partie lingulaire du poumon gauche se situe antérieurement à la chambre de chasse du ventricule droit (voir vidéo 08). (Avec la permission de $A Y$ Denault). ${ }^{7}$ Ao $=$ aorte LA $=$ oreillette gauche

\section{Limitations}

There are several limitations to using this echocardiographic-based approach. First, we have previously described that often more than one mechanism can explain the shock state. ${ }^{22}$ These mechanisms can act concomitantly, sequentially, and can also be interrelated. This may explain why so many studies in the ICU aimed at correcting only one specific factor have been unsuccessful, as there is likely more than one cause for shock. More than one intervention may then be necessary to correct the shock condition. For instance, severe hemorrhagic shock can lead to outflow tract obstruction if the patient is under-resuscitated. This is particularly true if the LV exhibits significant asymmetric septal, or severe concentric, hypertrophy. Right ventricular failure can be precipitated if excessive fluid resuscitation is undertaken, which, in turn, may incur LV diastolic dysfunction (the large right heart compresses the left heart and impairs filling) through interventricular dependence. This can lead to pulmonary edema and hypoxemia which will further worsen RV failure.

In some patients, adequate acoustic windows may not be obtained using TTE or surface ultrasound, and thus, TEE is indicated. When used in this setting, TEE imaging should not be limited just to the heart, but it can also be used to examine the lung and abdomen where extra-cardiac 

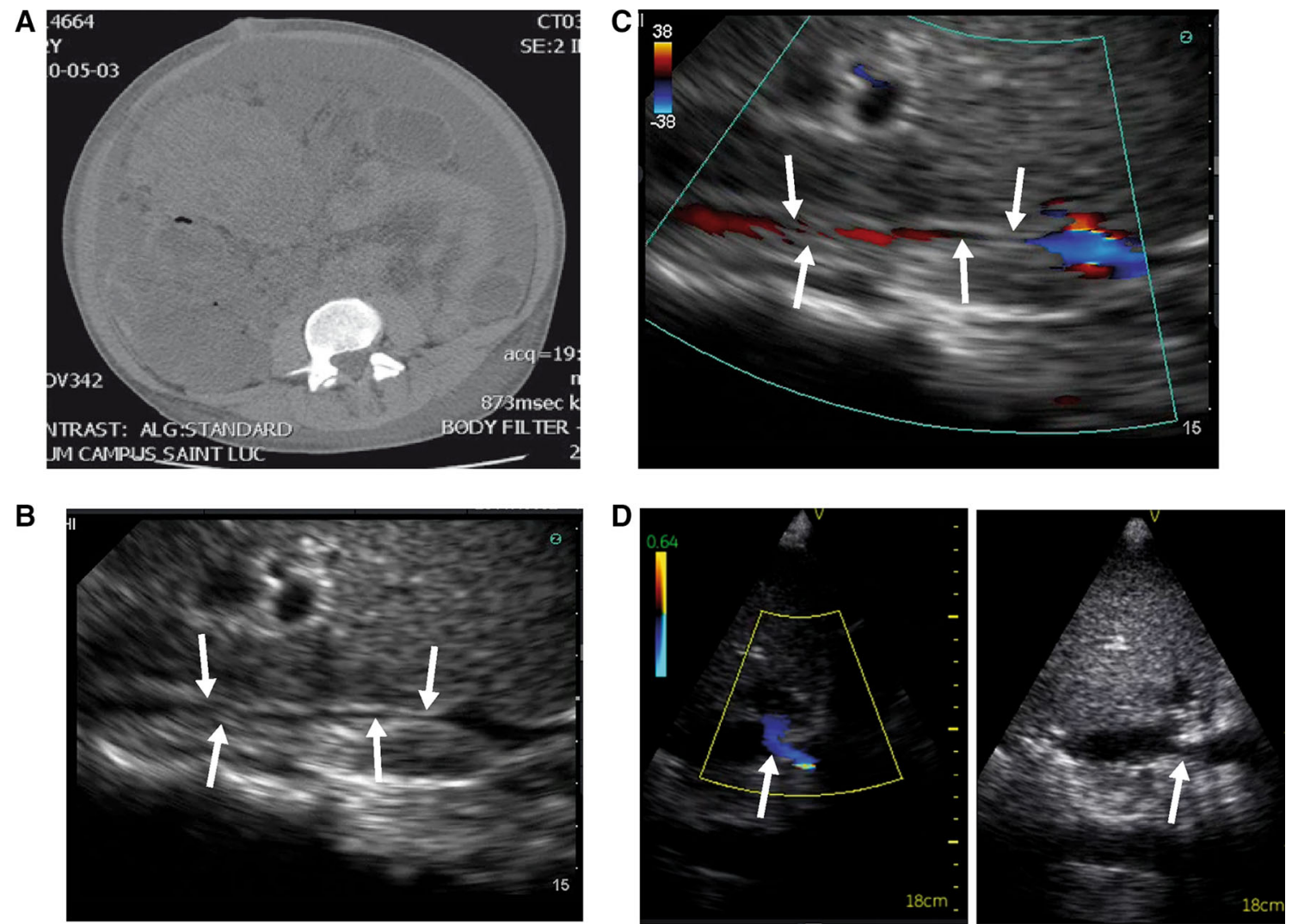

Fig. 9 Inferior vena cava in shock caused by increased venous resistance. (A) Axial computed tomography of a patient with abdominal compartment syndrome (B) Zoomed subxiphoid longitudinal view of the inferior vena cava (IVC) by ultrasound shows a reduced dimension of the IVC (arrows) (See video 09B). (C) In some patients, the compressed IVC can be identified only by using colour Doppler (arrows) (See video 09C). (D) Longitudinal subxiphoid view by ultrasound of a mechanical stenosis of the IVC (arrow) in a hemodynamically unstable patient after liver transplantation. Observe the colour flow acceleration (arrow) (See video 09D1) at the level of the IVC stenosis (See video 09D2). In this Figure, the head is positioned at the right of the image

pathology can be identified (Fig. 10). Finally, although bedside ultrasound can estimate cardiac output, this does not reflect the adequacy of oxygen transport. This can be done only by using arterial and venous blood gas for mixed venous oxygen tension, the veno-arterial carbon dioxide difference, ${ }^{26}$ lactate levels, and non-invasive cerebral or somatic oxygen spectroscopy. ${ }^{27,28}$ Nevertheless, the latter does not inform the clinician of the mechanism of reduced oxygen transport. Therefore, the use of both oxygen transport variables and bedside ultrasound should be considered when dealing with a patient in shock.

Training and certification

Adequate training and certification is necessary for the safe use of surface ultrasound or TEE as a point-of-care

Veine cave inférieure lors d'un choc provoqué par une résistance veineuse accrue. (A) Tomodensitométrie axiale d'un patient atteint d'un syndrome du compartiment abdominal. (B) Cette vue longitudinale sous-xiphoïdienne zoomée de la veine cave inférieure (VCI) par échographie montre sa dimension réduite (flèches) (voir vidéo 09B). (C) Chez certains patients, il n'est possible d'identifier la VCI comprimée qu'avec un Doppler couleur (flèches) (voir vidéo 09C). (D) Vue sous-xiphoïdienne longitudinale par échographie d'une sténose mécanique de la VCI (flèche) chez un patient instable hémodynamiquement après une greffe hépatique. Observez l'accélération du signal Doppler couleur (flèche) (voir vidéo 09D1) au niveau de la sténose de la VCI (voir vidéo 09D2). Dans cette figure, la tête est positionnée à la droite de l'image

diagnostic tool. The American College of Chest Physicians has developed a training and certification process for beside critical care ultrasound (http://www.chestnet.org/Education/ Advanced-Clinical-Training/Certificate-of-Completion-Pro gram/Critical-Care-Ultrasonography) that is currently used by several critical care programs. This process involves (1) a series of online lectures and specific courses, (2) creating a specific portfolio of ultrasound video clips, and (3) completing a comprehensive assessment examination that includes multiple choice questions and a practical exam. There is currently discussion amongst the cardiovascular, thoracic, and perioperative sections in the Canadian Anesthesiologists' Society (CAS) for the development or endorsement of a similar certification for anesthesiologists.

Objectives of the basic perioperative TEE examination were published by the Society of Cardiovascular 

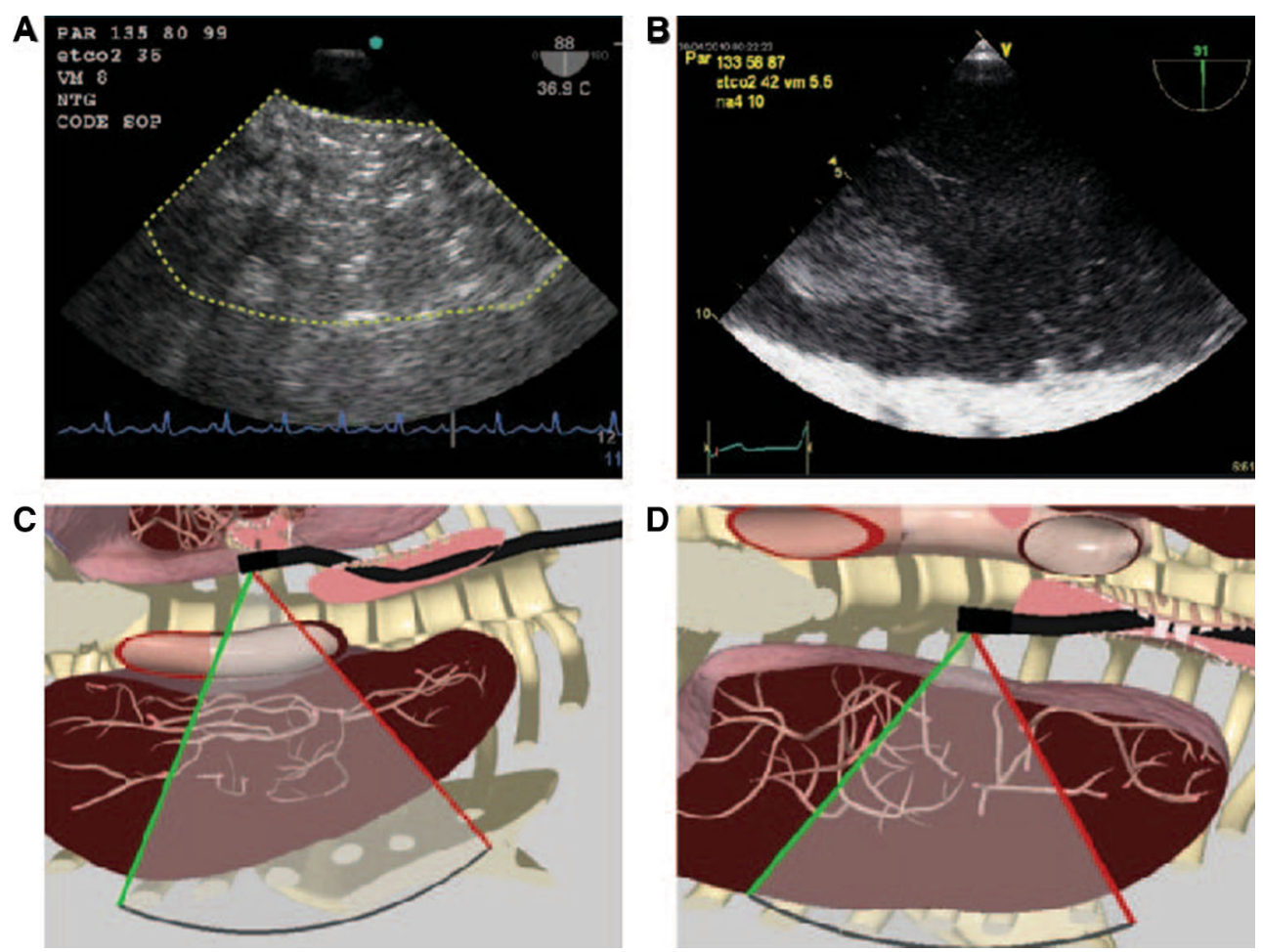

Fig. 10 Lung pathology diagnosed using TEE. Transesophageal echocardiographic (TEE) coronal views of (A) the mid portion of the left lung showing consolidation secondary to a pneumonia (dotted area) (See video 10A) and of (B) the right lung showing a hemothorax (See video 10B). (C-D) Anatomical position of the ultrasound beam in non-pathological lungs is shown using the VIMEDIX ${ }^{\circledR}$ simulator (CAE Healthcare, Saint-Laurent QC, Canada). (Adapted with permission from Denault AY et al. $)^{25}$

Anesthesiologists (SCA) and the American Society of Echocardiography (ASE) in 2013. ${ }^{29}$ Both societies advocate the use of basic TEE as a "monitoring" tool to aid in determining the cardiac causes of hemodynamic instability. The National Board of Echocardiography (NBE), based in the United States, administers the Examination of Special Competence in Adult Echocardiography $\left(\mathrm{ASCeXAM}^{\circledR}\right)$, the Examination of Special Competence in Basic Perioperative Echocardiography (Basic PTEeXAM ${ }^{\circledR}$ ) and oversees a certification process in basic TEE.

Online education is rapidly expanding and ranges from free website resources (http://pie.med.utoronto.ca) to extensive learning programs to assist physicians in learning and performing bedside ultrasound. An American Society of Anesthesiologists (ASA)/SCA basic perioperative TEE online course, accredited by the NBE, is available to provide interpretive experience. The SCA conducts online education courses in clinical ultrasound, including TEE or surface ultrasound for lung, basic abdomen, and deep venous thrombosis scanning (SCA

Pathologie pulmonaire diagnostiquées par ÉTO. Vues coronales pulmonaires par échocardiographie transœsophagienne (ÉTO) de (A) la partie médiane du poumon gauche montrant une consolidation secondaire à une pneumonie (zone en pointillé) (voir vidéo $10 \mathrm{~A}$ ) et (B) du poumon droit montrant un hémothorax (voir vidéo 10B). (C-D) La position anatomique du faisceau échographique est montrée dans des poumons non pathologiques à l'aide du simulateur VIMEDIX ${ }^{\circledR}$ (CAE Healthcare, Saint-Laurent QC, Canada). (Adapté avec la permission de AY Denault et coll. $)^{25}$

On-CUE program Levels 1 and 2). These courses provide extensive knowledge and reinforcement of interpretation with each level representing 400 hours of learning. Furthermore, the availability of high-fidelity simulators has facilitated the integration of knowledge with practical skills to aid training in bedside ultrasound. The use of simulators in workshops and individual learning provides a unique opportunity to scan "patients" with simulated pathology.

Goal-directed ultrasound is appealing to all anesthesiologists as training involves mastery of a limited amount of knowledge, pattern recognition of pathology, and fewer cases to achieve competence. ${ }^{30,31}$ For any interested anesthesiologist and critical care physician, basic TEE certification is being incorporated into several anesthesia training programs. Training in point-of-care ultrasound (POCUS) should start early in the anesthesia residency. At McGill University, the University of Toronto, and many medical schools worldwide, POCUS is now part of the curriculum in the first year of medical school. 


\section{Conclusion}

All anesthesiologists and critical care physicians will encounter patients with hemodynamic instability during their practice. The mechanism and etiology of shock must be identified rapidly in order to institute the best therapy. Clues from the patient's medical history, physical examination, and laboratory data and close examination of the hemodynamic and respiratory monitors will often be sufficient in order to resuscitate the patient successfully. However, in some patients, performing a bedside ultrasound will be essential for an immediate assessment of the heart, lung and abdomen, as currently done in emergency and critical care medicine. Bedside ultrasound is a skill that every anesthesiologist should be encouraged to acquire. ${ }^{32,33}$

\section{Clinical case}

A 67-yr-old female (weight $48 \mathrm{~kg}$ ) with diabetes, chronic obstructive pulmonary disease, and coronary artery disease presents to hospital with an acute abdomen. A diagnosis of bowel perforation with peritonitis is confirmed with computed tomography. In the operating room, following the induction of anesthesia using adequate peripheral venous and arterial access, her systolic blood pressure is $80 \mathrm{mmHg}$ with a heart rate of 110 beats. $\mathrm{min}^{-1}$. The patient responds to the administration of fluid and remains stable throughout the procedure. At the end of the case, however, during abdominal closure, she becomes hypotensive and no longer responds to fluid administration. Noradrenaline is started, and despite escalating doses, her systolic blood pressure remains $85 \mathrm{mmHg}$. The patient is transferred to the recovery room and is breathing spontaneously.

\section{Instructions for completing the Continuing Professional Development (CPD) module:}

1. Read the current article and the references indicated in bold.

2. Go to: http://www.cas.ca/Members/CPD-Online and select the current module (online title: Bedside clinical $\&$ ultrasound-based approaches to shock - Part II: Point-of-care ultrasound).

3. Answer the multiple choice questions regarding the case scenario.

4. Once you have entered all of your answers, you will have access to experts' explanations for all the possible choices.

5. Participants may claim up to four hours of CPD for a total of 12 credits under Section 3 of the CPD program of the Royal College of Physicians and Surgeons of Canada.

\section{Approches cliniques et échographiques au chevet du patient pour la gestion de l'instabilité hémodynamique - $2^{\mathrm{e}}$ partie: l'échographie au chevet en cas de choc hémodynamique}

Résumé On définit le choc comme une situation dans laquelle le transport d'oxygène est incapable de répondre à la demande en oxygène. On évalue le patient en état de choc en fonction de ses antécédents médicaux, de l'examen physique, ainsi que de l'observation minutieuse des moniteurs hémodynamiques et respiratoires. Le patient est d'abord pris en charge à l'aide de mesures de réanimation de base; toutefois, si l'instabilité hémodynamique persiste, il convient de réaliser une échographie au chevet. Nous proposons d'utiliser une échographie de la veine cave inférieure (VCI) dans le cadre du concept du retour veineux, comme première étape dans l'identification du mécanisme du choc. L'examen Doppler des veines hépatiques peut également être ajouté. Un examen échographique plus approfondi du cœur, du thorax et de l'abdomen du patient peut être réalisé par la suite afin de déterminer l'étiologie du choc. Chez les patients dont la pression veineuse systémique est réduite, on peut envisager un examen des cavités thoracique et abdominale afin de détecter du liquide libre, une pneumonie ou un empyème. Chez les patients dont la pression auriculaire droite est accrue, une échocardiographie transthoracique permettra d'identifier le mécanisme du dysfonctionnement ventriculaire gauche ou droit. Enfin, si le retour veineux rencontre une résistance accrue, on peut envisager de réaliser un examen thoracique afin d'exclure la présence de pneumothorax ou de tamponnade cardiaque et un examen abdominal pour détecter les signes d'un syndrome du compartiment abdominal ou d'une occlusion de la VCI. Le traitement subséquent peut alors être personnalisé en fonction de l'étiologie du choc. Des éléments de l'examen échographique au chevet sont actuellement enseignés dans de nombreux programmes de formation en anesthésiologie.

Objectif Mettre au point une approche du patient en état de choc qui incorpore l'examen échographique au chevet.

Objectifs de ce module de développement professionnel continu (DPC):

Après avoir lu ce module, le lecteur devrait être en mesure de:

1. Déterminer les indications pour une échographie au chevet du patient. 
2. Utiliser l'échographie au chevet pour identifier les principaux éléments vasculaires, cardiaques, pulmonaires et abdominaux qui permettront d'identifier l'étiologie du choc.

3. Mettre au point une approche systématique combinant les variables hémodynamiques, respiratoires et échocardiographiques pour évaluer le patient en état de choc.

4. Identifier les limites de l'échographie au chevet.

5. Reconnaître les modalités de formation et d'accréditation proposées en matière d'échographie au chevet.

\section{$2^{\mathrm{e}}$ partie}

\section{Introduction}

De nombreuses approches ont été proposées pour utiliser l'échographie au chevet auprès des patients en état de choc, notamment les protocoles FOCUSED, ${ }^{1}$ FATE, ${ }^{2}$ FAST, ${ }^{3}$ $\mathrm{RUSH}^{4}$ et HEART $\operatorname{scan}^{5}$ (Tableau 1). Le point commun de tous ces protocoles est le recours à une « échographie au point d'intervention ${ }^{6}$ qui met l'accent sur les trois éléments suivants: (1) l'examen est réalisé au chevet par le clinicien qui a la charge du patient; (2) les images dynamiques sont corrélées au cas clinique; et (3) l'examen peut être répété aussi souvent que nécessaire pour surveiller l'évolution du patient.

L'approche clinique que nous proposons intègre divers aspects de l'échographie au chevet, notamment l'examen du thorax, du cœur, de l'abdomen et des vaisseaux. Elle classe les trois mécanismes fondamentaux du choc selon le concept du retour veineux en: (1) une réduction de la pression veineuse systémique moyenne, (2) une augmentation de la pression auriculaire droite, et (3) une augmentation de la résistance au retour veineux (Tableau 2). Cette approche est le sujet d'une thèse de doctorat ${ }^{7}$. Elle a été mise en pratique depuis 1993 à l'unité des soins intensifs (USI) du Centre Hospitalier de l'Université de Montréal et de l'Institut de Cardiologie de Montréal (ICM) en utilisant une échographie de surface au chevet depuis 1996 et à l'ICM en salle d'opération en utilisant l'échocardiographie transœsophagienne (ÉTO) dans plus de 22000 cas.

Bien que l'échocardiographie transthoracique (ÉTT) et l'ÉTO puissent toutes deux être utilisées au chevet, l'emphase sera mise ici sur l'ÉTT, étant donné que cette technique est plus facilement disponible pour tous les anesthésiologistes et les intensivistes. Enfin, nous ne détaillons pas l'examen des poumons étant donné que notre approche de l'hypoxémie a fait l'objet d'un article de synthèse récent. ${ }^{8}$

Tableau 2 Classification des chocs selon le concept de retour veineux

\begin{tabular}{|c|c|c|}
\hline $\begin{array}{l}\text { Pression veineuse } \\
\text { systémique } \\
\text { moyenne réduite }\end{array}$ & $\begin{array}{l}\text { Pression } \\
\text { auriculaire } \\
\text { droite accrue }\end{array}$ & $\begin{array}{l}\text { Résistance accrue au retour } \\
\text { veineux }\end{array}$ \\
\hline $\begin{array}{l}\text { Choc hémorragique } \\
\text { Externe } \\
\text { Interne: thorax, } \\
\text { abdominal } \\
\text { Choc distributif } \\
\text { Septique } \\
\text { Non septique: } \\
\text { anaphylactique } \\
\text { neurogène } \\
\text { addisonien } \\
\text { bloc neuraxial } \\
\text { pharmacologique }\end{array}$ & $\begin{array}{l}\text { Dysfonction } \\
\text { systolique et } \\
\text { diastolique } \\
\text { (ischémique ou } \\
\text { non } \\
\text { ischémique) } \\
\text { Insuffisance } \\
\text { valvulaire } \\
\text { aiguë } \\
\text { Obstruction des } \\
\text { chambres de } \\
\text { chasse } \\
\text { Embolie } \\
\text { pulmonaire } \\
\text { Hypoxémie et } \\
\text { hypercapnie }\end{array}$ & $\begin{array}{l}\text { Extrinsèque: } \\
\text { Supra-diaphragmatique: } \\
\text { tamponnade } \\
\text { pneumothorax } \\
\text { tamponnade médiastinale } \\
\text { hyperinflation grave (PEEP } \\
\text { générée par l'individu) } \\
\text { Infra-diaphragmatique: } \\
\text { syndrome du compartiment } \\
\text { abdominal (intraluminal, } \\
\text { extraluminal et pariétal) } \\
\text { Intrinsèque: Obstruction de la } \\
\text { VCI à cause de sutures, } \\
\text { tumeurs, dispositifs }\end{array}$ \\
\hline
\end{tabular}

Tableau 1 Protocoles courants d'échographie au chevet

\begin{tabular}{|c|c|c|c|}
\hline \multicolumn{2}{|l|}{ Protocole } & \multirow{2}{*}{$\begin{array}{l}\text { Site de } \\
\text { l'échographie } \\
\text { ÉTT }\end{array}$} & \multirow{2}{*}{$\begin{array}{l}\text { Évaluation } \\
\text { Cardiaque }\end{array}$} \\
\hline FOCUSED & 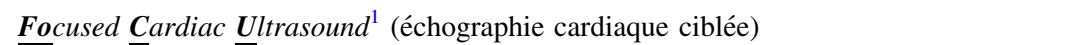 & & \\
\hline FATE & $\overline{\boldsymbol{F}}$ ocused $\underline{\boldsymbol{A}}$ ssessed $\underline{\boldsymbol{T}}$ ransthoracic $\underline{\boldsymbol{E}}$ cho $^{2}$ (échographie transthoracique évaluée ciblée) & ÉTT + pleural & $\begin{array}{l}\text { Cardiaque et } \\
\text { poumons }\end{array}$ \\
\hline FAST & 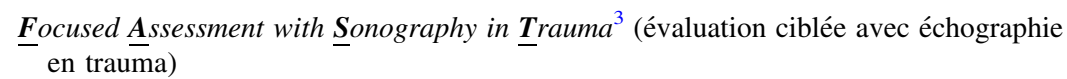 & $\begin{array}{l}\text { ÉTT, pleural, } \\
\text { abdominal }\end{array}$ & $\begin{array}{l}\text { Cardiaque, poumons } \\
\text { et abdomen }\end{array}$ \\
\hline RUSH & 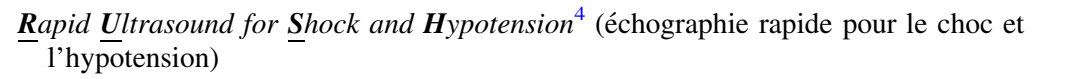 & $\begin{array}{l}\text { ÉTT, pleural, } \\
\text { abdomen }\end{array}$ & $\begin{array}{l}\text { Cardiaque, poumons } \\
\text { et abdomen }\end{array}$ \\
\hline HEARTscan & 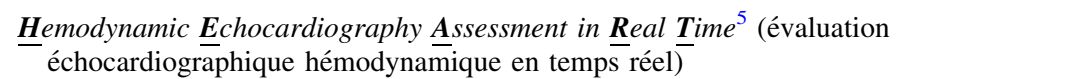 & Vues ÉTT & $\begin{array}{l}\text { Cardiaque, } \\
\text { hémodynamie }\end{array}$ \\
\hline
\end{tabular}

ÉTT $=$ échocardiographie transthoracique 
Tableau 3 Limites de l'utilisation de la VCI pour estimer la pression veineuse systémique moyenne

\section{Obstruction mécanique: \\ valve d'Eustache proéminente, tissu membraneux ou autre, tumeur, thrombus, anévrysme aortique, corps étranger tel que filtres présents dans la VCI, rétrécissement de la jonction VCI - oreillette droite \\ Autres: \\ entraînement athlétique, surface corporelle importante, ventilation mécanique}

$\mathrm{VCI}=$ veine cave inférieure. (adapté de Beigel et coll. . $^{34}$

\section{Examen d'échographie}

\section{Évaluation ultrasonographique de la veine cave inférieure}

La première étape, en présence d'un patient hémodynamiquement instable et ne répondant pas aux soins standards, est d'identifier le mécanisme sous-jacent du choc. Ce mécanisme peut être déterminé en réalisant un examen rapide de la taille et de la variation respiratoire de la veine cave inférieure (VCI) chez le patient respirant spontanément. L'examen échographique de la VCI est en général réalisé via une vue sous-xiphoïdienne (Fig. 1-1). Chez certains patients, la présence de drains thoraciques ou de pansements pourrait entraver l'accès à cette vue. Heureusement, étant donné que la partie distale de la VCI est située à l'intérieur du foie et que ce dernier est volumineux, il est possible d'accéder à une fenêtre acoustique montrant la VCI à travers le foie à partir des espaces intercotaux inférieurs droits (Fig. 1-2 \& 1-3). Notre prédilection pour la VCI plutôt que le cœur pour réaliser cette première partie de l'examen échographique du patient en état de choc découle du fait qu'il est possible d'obtenir des images de la VCI chez la vaste majorité des patients. Toutefois, l'utilisation de la VCI pour estimer la pression veineuse systémique moyenne comporte certaines limites (voir Tableau 3).

Chez une personne normale ventilée mécaniquement, la taille de la VCI augmente pendant l'inspiration (en raison de la pression intrathoracique accrue) et diminue pendant l'expiration. Il s'agit donc d'une inversion du schéma respiratoire observé chez les patients respirant spontanément. On peut néanmoins utiliser les changements de diamètre de la VCI pour évaluer la réponse aux liquides chez les patients dont les poumons sont ventilés de façon mécanique. ${ }^{9}$

Afin d'identifier l'étiologie sous-jacente précise provoquant le choc, il faut également examiner le cœur. Une façon simple de visualiser le cœur depuis la vue sous-xiphoïdienne de la VCI est de faire tourner la sonde d'échographie dans le sens horaire afin d'obtenir une vue sous-costale montrant les quatre chambres cardiaques, ce qui est similaire à une vue apicale des quatre chambres par ÉTT (Fig. 2). Outre l'approche sous-xiphoïdienne, il existe plusieurs autres vues échocardiographiques utiles pour l'examen du cœur, décrites notamment par Royse et coll. ${ }^{10}$

\section{Ultrasonographie en présence d'une pression veineuse systémique basse}

Chez les patients respirant spontanément, une pression veineuse systémique moyenne réduite est typiquement associée à une petite VCI dont les dimensions varient au rythme de la respiration. On peut facilement observer une telle situation à l'aide d'images 2D ou en mode M (Fig. 3). Une autre caractéristique échocardiographique utile pour évaluer la pression veineuse systémique moyenne est l'observation, dans la veine hépatique, du flux veineux hépatique $(\mathrm{FVH})$ qui sera normal à l'aide du Doppler pulsé. Le FVH normal génère une onde Doppler de forme triphasique (Fig. 4). Dans certains cas où la pression veineuse systémique moyenne est réduite, la vélocité du FVH peut être augmentée parce que la veine hépatique est alors plus petite, accélérant ainsi le flot sanguin qui la traverse. L'analyse de l'onde Doppler de la veine hépatique va au-delà des objectifs de cet article, mais Scheinfeld et McNaughton en ont fait d'excellents comptes rendus. ${ }^{11,12}$

Une fois que la pression veineuse systémique moyenne réduite est identifiée en tant que mécanisme du choc, la prochaine étape est d'en déterminer l'étiologie. Les pertes sanguines et la vasodilatation sont deux causes possibles. La mesure de l'hémoglobine au chevet permet de faire rapidement la distinction entre ces deux causes, bien que dans les cas d'hémorragies aiguës, les valeurs d'hématocrite peuvent demeurer normales pendant un certain temps; en effet, la réduction des érythrocytes est initialement associée à une réduction concomitante du volume plasmatique. ${ }^{13,14}$ Les pertes de sang peuvent être externes ou internes, y compris dans le thorax, la cavité péritonéale, la cavité rétropéritonéale, le bassin, les os longs ou le tractus gastro-intestinal. Il est facile d'identifier un hémothorax et du liquide libre dans l'abdomen (Fig. 5A-C) avec une échographie au chevet. L'hémorragie rétropéritonéale est plus difficile à diagnostiquer avec l'échographie; la tomodensitométrie (CT scan) constitue alors une meilleure modalité diagnostique (Fig. 5D-F). Chez certains patients, des caillots sanguins peuvent être observés dans l'estomac par ÉTT ou ÉTO (Fig. 6). L'échographie n'est pas aussi fiable que l'endoscopie haute ou basse pour diagnostiquer les saignements gastro-intestinaux. En effet, sur les images échographiques, le sang dans l'estomac peut ressembler aux solutions entérales. 
Si la perte de sang n'est pas la cause de la réduction de la pression veineuse systémique moyenne, il convient alors d'écarter la possibilité de sepsis en réalisant des examens cliniques et en laboratoire. Des vues limitées du cœur par ÉTT pourraient montrer des végétations importantes. L'échographie permet de diagnostiquer facilement une consolidation pulmonaire et une effusion complexe dans le thorax ou l'abdomen (Fig. 7). Les diagnostics d'abcès hépatique, de cholécystite et de pyélonéphrite nécessitent des compétences plus avancées en matière d'échographie au chevet. L'échographie au chevet n'est que d'une utilité limitée pour identifier certaines pathologies associées au choc distributif, par ex. les états de choc anaphylactique, de vasoplégie d'origine pharmacologique, ou de crise addisonienne.

L'échocardiographie peut aider à distinguer une hypovolémie d'une vasodilatation. Dans le cas de l'hypovolémie, les ventricules ont en général une petite taille (volume) en fin de diastole et de systole avec une fraction d'éjection normale. Chez un patient vasodilaté, la taille en fin de diastole sera normale avec une petite taille en fin de systole, ce qui représente une éjection accrue de sang contre une résistance moindre. Toutefois, cette distinction peut être difficile à établir dans des états hémodynamiques évoluant rapidement lorsque les deux conditions sont simultanément présentes chez des patients pour lesquels nous ne connaissons pas le volume télédiastolique normal de base.

\section{Ultrasonographie en présence d'une pression de l'oreillette droite élevée}

En cas de choc cardiogénique, l'élévation de la pression auriculaire droite est associée à une VCI distendue sans variation respiratoire et à un profil Doppler du FVH qui montre un rapport systole: diastole réduit (Fig. 4). Si l'on soupçonne un choc cardiogénique, une évaluation échocardiographique approfondie est nécessaire afin de déterminer si la cause est liée à une pathologie du ventricule gauche (VG), du ventricule droit (VD), à une valvulopathie, à une hypertension pulmonaire, à une régurgitation tricuspidienne grave, à des shunts intracardiaques, ou à d'autres causes telles que l'embolie pulmonaire. La vue sous-xiphoïdienne des quatre chambres peut être utilisée pour dépister plusieurs de ces pathologies. La présence d'une dysfunction systolique peut indiquer la nécessité d'inotropes. L'évaluation de la fonction biventriculaire a fait l'objet de plusieurs revues détaillées. ${ }^{15,16}$ Il faut souligner que toutes les dépressions myocardiques ne sont pas d'origine ischémique. Par exemple, en cas de choc septique, une cardiomyopathie de stress peut être observée chez un nombre allant jusqu'à $60 \%$ des patients lorsqu'un examen échocardiographique est réalisé dans les trois jours suivant leur admission. ${ }^{17}$ Une insuffisance ventriculaire droite peut être provoquée par une embolie pulmonaire ou par une hypertension pulmonaire chronique, quelle qu'en soit la cause. Une tomodensitométrie pulmonaire demeure la modalité diagnostique à privilégier pour dépister l'embolie pulmonaire. Toutefois, l'échocardiographie 2D peut documenter un thrombus en transit et mettre en évidence les conséquences d'une obstruction de l'artère pulmonaire, telles qu'une dilatation du VD, une excursion systolique réduite et une oreillette gauche et un VG de petite taille, le côté gauche du cœur recevant moins de sang.

L'obstruction de la chambre de chasse du ventricule gauche et du ventricule droit peut augmenter la pression auriculaire droite. Ces pathologies se manifestent chez des patients prédisposés par leur anatomie et ayant une précharge réduite, ou chez ceux recevant des agents inotropes qui peuvent provoquer une tachycardie et réduire le temps de remplissage ventriculaire. ${ }^{18,19}$ L'administration de volume et de bêtabloquants (qui réduisent l'inotropie) corrigera souvent cette pathologie. Les critères diagnostiques des obstructions de la chambre de chasse gauche ou droite ont été décrit par le passé. ${ }^{19,20}$ La compression mécanique de la chambre de chasse du VD peut survenir lors d'un pneumothorax antérieur, dans quel cas l'obstruction ne sera d'abord observée qu'en diastole (Fig. 8). Cette condition a également été décrite en position ventrale ou avec un hématome médiastinal antérieur après une chirurgie cardiaque. ${ }^{21}$

La dysfonction diastolique du VG est une cause courante d'augmentation de la pression auriculaire droite et peut se présenter sous forme de choc cardiogénique. ${ }^{22}$ Très souvent, elle est associée à des oreillettes dilatées. Il existe deux formes d'insuffisance diastolique associées à (1) un petit VG et une fraction d'éjection normale, ou (2) un VG dilaté et une fraction d'éjection réduite. Il n'y a pas de traitement spécifique pour l'insuffisance cardiaque diastolique en période périopératoire, sauf le traitement de l'ischémie myocardique, s'il y a lieu. ${ }^{23}$

Enfin, l'hypoxémie et l'hypercapnie peuvent toutes deux provoquer une hypertension pulmonaire et une insuffisance $\mathrm{du}$ VD. Une échographie des poumons peut aider à déterminer s'il y a un pneumothorax, une effusion pleurale, une consolidation pulmonaire, une atélectasie et de la congestion. ${ }^{8}$ La présence à l'échographie pulmonaire d'un schéma d'oedème interstitiel dans toutes les zones pulmonaires suggère une congestion veineuse pulmonaire aiguë et, par conséquent, une insuffisance cardiaque plus grave. Dans les cas d'hypoxémie inexpliquée en l'absence de résistance ventilatoire ou de compliance pulmonaire réduite, les cliniciens devraient chercher un shunt intracardiaque (même une petite persistance du foramen ovale) avec un débit de droite à gauche. 
Ultrasonographie en présence d'une augmentation de la résistance au retour veineux

L'instabilité hémodynamique due à une résistance accrue au retour veineux est moins répandue et peut être insidieuse; si cette condition n'est pas diagnostiquée, elle entraîne bien souvent la mort. La VCI peut alors être petite ou dilatée, selon l'étiologie (Fig. 9). L'affichage spectral Doppler du FVH présente en général une onde de forme monophasique ou absente (Fig. 4) parce que la réduction du gradient de pression entre la pression veineuse systémique moyenne et la pression auriculaire droite diminue le flux veineux hépatique. La VCI sera en général petite et presque complètement comprimée chez les patients atteints d'un syndrome du compartiment abdominal. ${ }^{24}$ La VCI sera dilatée chez les patients présentant une tamponnade cardiaque ou médiastinale, un pneumothorax et une pression positive télé-expiratoire (PEEP) intrinsèque excessive, toutes ces situations réduisant le débit sanguin se dirigeant vers le coeur. Chez les patients atteints d'une occlusion iatrogénique ou intrinsèque de la VCI, la VCI intrahépatique sera également distendue. Cette condition peut survenir en cas de greffe du foie, de canulation de la VCI pendant une chirurgie cardiaque, ${ }^{25}$ ou lors de l'anastomose de la VCI pendant une greffe cardiaque. Dans de tels cas, les caractéristiques échocardiographiques clés sont un rétrécissement de la lumière de la VCI et une accélération du flux sur le Doppler couleur (Fig. 9). La confirmation du gradient hémodynamique par cathétérisation de la VCI est indiquée si l'on envisage l'implantation d'une prothèse endovasculaire.

Prise en charge du choc

Il est important d'identifier le mécanisme et l'étiologie du choc afin de choisir le meilleur traitement. Par exemple, une pression veineuse systémique moyenne réduite peut être traitée en administrant du volume, des produits sanguins, des antibiotiques et des vasopresseurs. Un examen de la VCI peut également servir à prédire la réponse à l'administration de liquides et à en mesurer l'effet chez un patient respirant spontanément ou chez un patient sous ventilation mécanique. ${ }^{9}$ Les mesures répétées de la taille et de la variation respiratoire de la VCI peuvent être plus sensibles que les mesures de la tension artérielle pour évaluer l'effet d'une réanimation liquidienne chez les patients. Les vasopresseurs peuvent être utiles pour éviter un remplissage excessif en présence de vasodilatation. Dans certains cas, la supplémentation stéroïdienne, les antihistaminiques, l'adrénaline, voire le bleu de méthylène, peuvent être envisagés pour traiter les états vasoplégiques réfractaires.

La prise en charge du choc associé à une pression auriculaire droite élevée dépend de l'étiologie sous-jacente telle que déterminée par l'échocardiographie. Par exemple, les agents inotropes devraient être envisagés s'il y a dysfonction systolique; par contre, ils sont contre-indiqués pour la prise en charge d'une obstruction de la chambre de chasse. Les agents administrés par inhalation tels que la prostacycline, la milrinone ou le monoxyde d'azote amélioreront la prise en charge d'une insuffisance du VD. Le maintien d'une pression artérielle systémique est également important afin de prendre en charge une insuffisance du VD. Cette dernière peut nécessiter plusieurs médicaments, comme par exemple un inodilatateur accompagné d'un vasopresseur. Une thrombolyse ou une chirurgie cardiaque urgente pourraient être indiquées en présence d'une embolie pulmonaire aiguë. L'hypoxémie et l'hypercapnie ne peuvent être convenablement corrigées que si une cause traitable est identifiée. L'utilisation de l'échographie du système respiratoire peut s'avérer fort utile dans ces situations.

Enfin, le traitement d'une résistance accrue au retour veineux est, en règle générale, non pharmacologique. Elle peut comprendre l'insertion de drains thoraciques efficaces, la ponction péricardique, la laparotomie, le positionnement du patient (grossesse) et l'ajustement du ventilateur dans le cas d'une auto-PEEP. Une importante effusion pleurale, une PEEP excessive (externe ou intrinsèque), la grossesse (utérus gravide), l'obésité morbide, l'ascite et l'épanchement péricardique sont tous des causes de compression de la VCI ou du cœur par voie extrinsèque ce qui pourrait induire une insuffisance diastolique. La tamponnade est une forme grave «d'insuffisance diastolique aiguë » dans laquelle le liquide péricardique comprime les chambres du cœur.

Limites

L'approche fondée sur l'échocardiographie comporte de nombreuses limites. En premier lieu, comme nous l'avons décrit par le passé, bien souvent, plus d'un mécanisme peut expliquer l'état de choc. ${ }^{22}$ Ces mécanismes peuvent agir de façon concomitante ou séquentielle, et ils peuvent également être liés. Cela pourrait expliquer pourquoi un si grand nombre d'études réalisées aux soins intensifs ayant pour objectif de corriger un facteur spécifique ont échoué, étant donné qu'il existe probablement plus d'une cause pour le choc. Dès lors, il se peut que plus d'une intervention soit nécessaire pour corriger la situation. Par exemple, un choc hémorragique grave peut entraîner une obstruction des chambres de chasse si le patient est sous-réanimé. Ceci est particulièrement vrai si le VG souffre d'une importante hypertrophie asymétrique septale ou concentrique. L'insuffisance ventriculaire droite peut être précipitée lorsqu'on entame une réanimation liquidienne excessive, ce qui peut subséquemment provoquer une dysfonction diastolique du VG (le volume 
du cœur droit comprime le cœur gauche et entrave le remplissage). Cela peut provoquer un œdème pulmonaire et de l'hypoxémie, empirant encore l'insuffisance du VD.

Chez certains patients, il peut être impossible d'obtenir des fenêtres acoustiques adéquates à l'aide de l'ÉTT ou de l'échographie de surface. Dans de tels cas, l'ÉTO est indiquée. Lorsqu'elle est utilisée dans un tel contexte, il convient de ne pas limiter l'imagerie d'ÉTO au cœur: elle peut également être utilisée pour examiner les poumons et l'abdomen, où des pathologies extra-cardiaques peuvent être identifiées (Fig. 10). Enfin, bien que l'échographie au chevet puisse estimer le débit cardiaque, cette mesure ne fournit que des renseignements partiels sur la qualité du transport d'oxygène. Pour mieux estimer l'apport en oxygène, il faut analyser les gaz sanguins, artériels et veineux, afin d'obtenir la tension d'oxygène du sang veineux mixte, mesurer la différence véno-artérielle en dioxyde de carbone, ${ }^{26}$ suivre les niveaux de lactate et/ou utiliser des mesures non invasives d'oxymétrie cérébrale ou somatique par spectroscopie à infrarouge. ${ }^{27,28}$ Toutefois, cette deuxième option ne donne pas d'informations au clinicien quant au mécanisme causant la réduction du transport d'oxygène. Il est donc souhaitable de prendre simultanément en compte les variables liées au transport d'oxygène et le résultat de l'échographie au chevet lorsqu' on traite un patient en état de choc.

\section{Formation et accréditation}

Une formation adéquate dûment accréditée est nécessaire pour garantir une utilisation optimale et sécuritaire de l'échographie de surface et de l'ÉTO comme outil diagnostique au chevet. L'American College of Chest Physicians a mis au point un processus de formation et d'accréditation pour l'échographie en soins critiques (http:// www.chestnet.org/Education/Advanced-Clinical-Training/ Certificate-of-Completion-Program/Critical-Care-Ultrasono graphy) qui est actuellement utilisé par plusieurs programmes de soins intensifs. Ce processus comporte (1) des cours, (2) la création d'un portfolio individuel de clips vidéo d'échographie, et (3) la complétion d'un examen d'évaluation exhaustif qui comprend des questions à choix multiples et un examen pratique. À l'heure actuelle, des discussions ont lieu au sein des sections cardiovasculaire, thoracique et périopératoire de la Société canadienne des anesthésiologistes afin de mettre au point ou d'endosser une accréditation semblable pour les anesthésiologistes.

Les objectifs de l'examen d'ÉTO périopératoire de base ont été publiés par la Society of Cardiovascular Anesthesiologists (SCA) et l'American Society of Echocardiography (ASE) en 2013. ${ }^{29}$ Les deux sociétés recommandent l'utilisation de l'ÉTO de base comme outil de «monitorage » afin d'aider à déterminer les causes cardiaques de l'instabilité hémodynamique. Le National Board of Echocardiography (NBE), basé aux États-Unis, administre l'examen de compétences spéciales en échocardiographie chez l'adulte (Examination of Special Competence in Adult Echocardiography - $\mathrm{ASCeXAM}^{\circledR}$ ), l'examen de compétences spéciales en échocardiographie périopératoire de base (Examination of Special Competence in Basic Perioperative Echocardiography - Basic PTEeXAM ${ }^{\circledR}$ ) et supervise un processus d'accréditation en ÉTO de base.

La formation en ligne prend un essor rapide et va de ressources web gratuites (http://pie.med.utoronto.ca) à des programmes d'apprentissage exhaustifs permettant aux médecins d'apprendre et de réaliser des échographies au chevet. Un cours en ligne d'ÉTO périopératoire de base de l'American Society of Anesthesiologists (ASA)/SCA, accrédité par le NBE, est disponible et offre de l'expérience en matière d'interprétation. La SCA propose des cours de formation en ligne en échographie clinique, y compris en ÉTO ou en échographie de surface pour l'examen des poumons, de l'abdomen de base et de la thrombose veineuse profonde (programme SCA On-CUE niveaux 1 et 2). Ces cours proposent des connaissances approfondies et renforcent les aptitudes d'interprétation, chaque niveau représentant $400 \mathrm{~h}$ d'apprentissage. En outre, la disponibilité de simulateurs haute fidélité a facilité l'intégration des connaissances aux compétences pratiques afin d'assister la formation en échographie au chevet. L'utilisation de simulateurs dans le cadre d'ateliers ou de d'apprentissages individuels offre une occasion unique d'examiner diverses pathologies simulées.

L'échographie ciblée représente un atout potentiel pour tous les anesthésiologistes. En effet, la formation ne requiert la maîtrise que d'une quantité limitée de connaissances, la reconnaissance de schémas pathologiques, et un nombre restreint de cas est suffisant afin d'acquérir les compétences nécessaires à sa pratique. ${ }^{30,31}$ Pour tous les anesthésiologistes et intensivistes intéressés, l'accréditation en ÉTO de base sera intégrée dans plusieurs programmes de formation en anesthésiologie. La formation en échographie au chevet ou point-of-care ultrasound (POCUS) devrait devrait démarrer tôt dans la résidence en anesthésiologie. À l'Université McGill, à l'Université de Toronto et dans de nombreuses écoles de médecine dans le monde, le POCUS fait désormais partie du programme de première année de médecine.

\section{Conclusion}

Tous les anesthésiologistes et intensivistes sont confrontés à l'instabilité hémodynamique au cours de leur pratique. Le mécanisme et l'étiologie du choc doivent être rapidement identifiés afin de mettre en place le meilleur traitement. Les 
antécédents médicaux, l'examen physique, les données de laboratoire et un examen minutieux des moniteurs hémodynamiques et respiratoires fourniront souvent des données suffisantes afin de procéder à la réanimation du patient. Toutefois, chez certains patients, la réalisation d'une échographie au chevet sera cruciale pour évaluer immédiatement le cœur, les poumons et l'abdomen, comme il se fait couramment à l'urgence et de plus en plus aux soins intensifs. La maîtrise de l'échographie au chevet est une compétence que chaque anesthésiologiste devrait être encouragé à acquérir. ${ }^{32,33}$

\section{Cas clinique}

Une femme de 67 ans (poids $48 \mathrm{~kg}$ ) souffrant de diabète, de maladie pulmonaire obstructive chronique et de maladie coronarienne se présente à l'hôpital avec un syndrome abdominal aigu. Un diagnostic de perforation intestinale accompagnée de péritonite est confirmé par tomodensitométrie. En salle d'opération, après l'induction de l'anesthésie à l'aide d'accès veineux et artériels périphériques adaptés, sa tension artérielle systolique est de $80 \mathrm{mmHg}$ et sa fréquence cardiaque de 110 battements $\cdot \min ^{-1}$. La patient répond à l'administration de liquides et demeure stable tout au long de l'intervention. À la fin du cas toutefois, pendant la fermeture de l'abdomen, elle devient hypotendue et ne répond plus à l'administration liquidienne. On démarre alors une perfusion de noradrénaline mais, malgré des doses croissantes, sa tension artérielle systolique demeure à $85 \mathrm{mmHg}$. La patiente est transférée en salle de réveil et respire spontanément.

\section{Directives pour compléter le module de développement professionnel continu (DPC):}

1. Lisez cet article et les références en gras.

2. Allez à: http://www.cas.ca/Members/CPD-Online et choisissez le module actuel (online title: Approches clinique et échographiques du choc au chevet du patient - Partie 2: l'échographie).

3. Répondez aux questions à choix de réponses concernant le cas clinique.

4. Une fois que vous avez saisi toutes vos réponses, vous aurez accès aux explications d'experts pour tous les choix possibles.

5. Les participants peuvent réclamer un maximum de quatre heures de DPC pour un total de 12 crédits sous la Section 3 du programme de DPC du Collège royal des médecins et chirurgiens du Canada.
Acknowledgements The authors sincerely thank Denis Babin and Antoinette Paolitto for their assistance in bringing this manuscript to fruition.

Funding sources Montreal Heart Institute Foundation.

Conflicts of interest None declared.

Sources de financement Fondation de l'Institut de cardiologie de Montréal.

Conflit d'intérêt Aucun.

\section{References}

Note References 35 to 37 are cited in the Clinical Case Question and Answers section of the CPD module that is available to CJA subscribers at http://www.cas.ca/ Members/CPD-Online.

1. Spencer KT, Kimura BJ, Korcarz CE, Pellikka PA, Rahko PS, Siegel RJ. Focused cardiac ultrasound: recommendations from the American Society of Echocardiography. J Am Soc Echocardiogr 2013; 26: 567-81.

2. Holm JH, Frederiksen CA, Juhl-Olsen P, Sloth E. Perioperative use of focus assessed transthoracic echocardiography (FATE). Anesth Analg 2012; 115: 1029-32.

3. Scalea TM, Rodriguez A, Chiu WC, et al. Focused Assessment with Sonography for Trauma (FAST): results from an international consensus conference. J Trauma 1999; 46: 466-72.

4. Perera $P$, Mailhot $T$, Riley D, Mandavia D. The RUSH exam: Rapid Ultrasound in SHock in the evaluation of the critically 111. Emerg Med Clin North Am 2010; 28: 29-56, vii.

5. Faris JG, Veltman $M G$, Royse CF. Limited transthoracic echocardiography assessment in anaesthesia and critical care. Best Pract Res Clin Anaesthesiol 2009; 23: 285-98.

6. Moore CL, Copel JA. Point-of-care ultrasonography. N Engl J Med 2011; 364: 749-57.

7. Denault $A Y$. Difficult separation from cardiopulmonary bypass:importance, mechanism and prevention (PhD Thesis: https://papyrus.bib.umontreal.ca/xmlui/handle/1866/4241). Université de Montréal, 2010.

8. Piette E, Daoust $R$, Denault A. Basic concepts in the use of thoracic and lung ultrasound. Curr Opin Anaesthesiol 2013; 26: 20-30.

9. Toupin F, Denault A, Lamarche $Y$, Deschamps A. Hemodynamic instability and fluid responsiveness. Can J Anesth 2013; 60: 1240-7.

10. Royse CF, Canty DJ, Faris J, Haji DL, Veltman M, Royse A. Core review: physician-performed ultrasound: the time has come for routine use in acute care medicine. Anesth Analg 2012; 115: 1007-28.

11. Scheinfeld $M H$, Bilali A, Koenigsberg $M$. Understanding the spectral Doppler waveform of the hepatic veins in health and disease. Radiographics 2009; 29: 2081-98.

12. McNaughton DA, Abu-Yousef MM. Doppler US of the liver made simple. Radiographics 2011; 31: 161-88.

13. Valeri $C R$, Dennis $R C$, Ragno $G$, Macgregor $H$, Menzoian JO, Khuri SF. Limitations of the hematocrit level to assess the need for red blood cell transfusion in hypovolemic anemic patients. Transfusion 2006; 46: 365-71.

14. Warkentin TE. Systematic underestimation of anemia severity in postoperative patients. Transfusion 2006; 46: 317-8. 
15. Lang RM, Bierig $M$, Devereux $R B$, et al. Recommendations for chamber quantification: a report from the American Society of Echocardiography's Guidelines and Standards Committee and the Chamber Quantification Writing Group, developed in conjunction with the European Association of Echocardiography, a branch of the European Society of Cardiology. J Am Soc Echocardiogr 2005; 18: 1440-63.

16. Rudski LG, Lai WW, Afilalo J, et al. Guidelines for the echocardiographic assessment of the right heart in adults: a report from the American Society of Echocardiography Endorsed by the European Association of Echocardiography, a registered branch of the European Society of Cardiology, and the Canadian Society of Echocardiography. J Am Soc Echocardiogr 2010; 23: 685-713.

17. Vieillard-Baron A, Caille V, Charron C, Belliard $G$, Page B, $J \operatorname{ardin} F$. Actual incidence of global left ventricular hypokinesia in adult septic shock. Crit Care Med 2008; 36: 1701-6.

18. Denault AY, Chaput M, Couture P, Hebert Y, Haddad F, Tardif $J C$. Dynamic right ventricular outflow tract obstruction in cardiac surgery. J Thorac Cardiovasc Surg 2006; 132: 43-9.

19. Rochon AG, L'Allier PL, Denault $A Y$. Always consider left ventricular outflow tract obstruction in hemodynamically unstable patients. Can J Anesth 2009; 56: 962-8.

20. Haddad F, Couture P, Tousignant C, Denault AY. The right ventricle in cardiac surgery, a perioperative perspective: II. Pathophysiology, clinical importance, and management. Anesth Analg 2009; 108: 422-33.

21. Neira VM, Gardin L, Ryan G, Jarvis J, Roy D, Splinter W. A transesophageal echocardiography examination clarifies the cause of cardiovascular collapse during scoliosis surgery in a child. Can J Anesth 2011; 58: 451-5.

22. Costachescu T, Denault A, Guimond JG, et al. The hemodynamically unstable patient in the intensive care unit: hemodynamic vs. transesophageal echocardiographic monitoring. Crit Care Med 2002; 30: 1214-23.

23. Alsaddique AA, Royse AG, Royse CF, Fouda MA. Management of diastolic heart failure following cardiac surgery. Eur J Cardiothorac Surg 2009; 35: 241-9.

24. Deslauriers N, Dery $R$, Denault A. Acute abdominal compartment syndrome. Can J Anesth 2009; 56: 678-82.

25. Denault AY, Couture P, Vegas A, Buithieu J, Tardif JC. Transesophageal Echocardiography Multimedia Manual Second edition: A Perioperative Transdisciplinary Approach. New York: Informa Healthcare; 2011.
26. Johnson BA, Weil MH. Redefining ischemia due to circulatory failure as dual defects of oxygen deficits and of carbon dioxide excesses. Crit Care Med 1991; 19: 1432-8.

27. Ghosh A, Elwell C, Smith M. Review article: cerebral nearinfrared spectroscopy in adults: a work in progress. Anesth Analg 2012; 115: 1373-83.

28. Harel F, Denault A, Ngo Q, Dupuis J, Khairy P. Near-infrared spectroscopy to monitor peripheral blood flow perfusion. J Clin Monit Comput 2008; 22: 37-43.

29. Reeves ST, Finley AC, Skubas NJ, et al. Special article: Basic perioperative transesophageal echocardiography examination: a consensus statement of the American Society of Echocardiography and the Society of Cardiovascular Anesthesiologists. Anesth Analg 2013; 117: 543-58.

30. Vignon P, Dugard A, Abraham J, et al. Focused training for goaloriented hand-held echocardiography performed by noncardiologist residents in the intensive care unit. Intensive Care Med 2007; 33: 1795-9.

31. Vignon $P$, Mucke $F$, Bellec $F$, et al. Basic critical care echocardiography: validation of a curriculum dedicated to noncardiologist residents. Crit Care Med 2011; 39: 636-42.

32. Denault AY, Rochon AG. Transesophageal echocardiography training: looking forward to the next step. Can J Anesth 2011; 58: 1-7.

33. Denault A, Fayad A, Chen R. Focused ultrasound is the next step in perioperative care. Can J Anesth 2013; 60: 741-7.

34. Beigel R, Cercek B, Luo H, Siegel RJ. Noninvasive evaluation of right atrial pressure. J Am Soc Echocardiogr 2013; 26: 1033-42.

35. American Society of Anesthesiologists and the Society of Cardiovascular Anesthesiologists Task Force on Transesophageal Echocardiography. Practice guidelines for perioperative transesophageal echocardiography. An updated report by the American Society of Anesthesiologists and the Society of Cardiovascular Anesthesiologists Task Force on Transesophageal Echocardiography. Anesthesiology 2010; 112: 1084-96.

36. Lapointe $V$, Jocov D, Denault A. Hemodynamic instability in septic shock. Can J Anesth 2009; 56: 864-7.

37. Bainbridge D, Cheng D. Stress-induced cardiomyopathy in the perioperative setting. Can J Anesth 2009; 56: 397-401. 